\title{
The impact of smoking cessation on respiratory symptoms, lung function, airway hyperresponsiveness and inflammation
}

\author{
B.W.M. Willemse*,\#, D.S. Postma* , W. Timens*, N.H.T. ten Hacken ${ }^{\#}$
}

The impact of smoking cessation on respiratory symptoms, lung function, airway hyperresponsiveness and inflammation. B.W.M. Willemse, D.S. Postma, W. Timens, N.H.T. ten Hacken. C) ERS Journals Ltd 2004.

ABSTRACT: Smoking is the main risk factor in the development of chronic obstructive pulmonary disease (COPD), and smoking cessation is the only effective treatment for avoiding or reducing the progression of this disease.

Despite the fact that smoking cessation is a very important health issue, information about the underlying mechanisms of the effects of smoking cessation on the lungs is surprisingly scarce. It is likely that the reversibility of smoke-induced changes differs between smokers without chronic symptoms, smokers with nonobstructive chronic bronchitis and smokers with COPD. This review describes how these three groups differ regarding the effects of smoking cessation on respiratory symptoms, lung function (forced expiratory volume in one second), airway hyperresponsiveness, and pathological and inflammatory changes in the lung.

Smoking cessation clearly improves respiratory symptoms and bronchial hyperresponsiveness, and prevents excessive decline in lung function in all three groups.

Data from well-designed studies are lacking regarding the effects on inflammation and remodelling, and the few available studies show contradictory results. In chronic obstructive pulmonary disease, a few histopathological studies suggest that airway inflammation persists in exsmokers. Nevertheless, many studies have shown that smoking cessation improves the accelerated decline in forced expiratory volume in one second, which strongly indicates that important inflammatory and/or remodelling processes are positively affected.

Eur Respir J 2004; 23: 464-476.
Depts of *Pathology, and ${ }^{*}$ Pulmonology, University Hospital Groningen, Groningen, the Netherlands.

Correspondence: B.W.M. Willemse

Dept of Pathology

University Hospital Groningen

Hanzeplein 1

9713 GZ Groningen

The Netherlands

Fax: 31503632510

E-mail: b.w.m.willemse@path.azg.nl

Keywords: Chronic obstructive pulmonary disease

inflammation

review

smoking cessation

Received: February 52003

Accepted after revision: October 292003
Smoking may lead to clinically recognised chronic obstructive pulmonary disease (COPD) in $15-20 \%$ of those who smoke. COPD is characterised clinically by chronic respiratory symptoms such as cough and sputum production, airflow limitation (according to the European Respiratory Society (ERS), a forced expiratory volume in one second (FEV1)/vital capacity (VC) ratio of $<88 \%$ of the predicted value in males or $<89 \%$ pred in females) and an accelerated decline in FEV1 $\left(>50 \mathrm{~mL} \cdot \mathrm{yr}^{-1}\right)$. Smoking is the most important risk factor for developing COPD [1], and smoking cessation is the only effective treatment slowing down the accelerated decline in FEV1 [2, 3]. Pathological changes in the airways of COPD patients are increased with respect to: 1$)$ the number and size of glands, 2) inflammation, 3) fibrosis, and 4) destruction of alveolar attachments. In contrast, almost $50 \%$ of smokers develop chronic bronchitis, i.e. chronic respiratory symptoms without airway obstruction [1]. Chronic bronchitis is characterised by chronic cough and sputum production, being associated with the abundant presence of mucus-producing elements in the large airways. Approximately $30 \%$ of smokers do not show chronic symptoms or abnormal lung function. Nevertheless, even these so-called "healthy smokers" show subtle changes in lung morphology, lung inflammation and lung function [4-9]. Smoking, apparently, always affects the lungs, although the extent and severity of these changes differ between individuals. The question arises as to whether the reversibility of these changes also differs after smoking cessation. Consequently, the primary aim of the present review is to provide an overview of the effects of smoking cessation on respiratory symptoms, lung function (FEV1 and extent of longitudinal decline in FEV1), bronchial hyperresponsiveness, and the pathological and inflammatory changes in the lungs of the above-mentioned groups. Furthermore, important clinical variables are compared with the underlying pathological and inflammatory changes after smoking cessation.

\section{Definitions, selection of articles and structure}

Smokers were defined according to the definitions given in table 1. ERS (1995) [1] rather than Global Initiative for Chronic Obstructive Lung Disease [10] criteria were used for chronic bronchitis and COPD, since most articles included in the present review were written before the introduction of these guidelines. References to chronic bronchitis are to the "pure" nonobstructive form. Especially in large general population studies, it was sometimes difficult to allocate subjects to one of the above-described groups, since, in such studies, all subjects were regarded as healthy at inclusion and yet, afterwards, some of them could be defined as having chronic bronchitis or asthma. Data from patients with asthma were excluded but not data regarding atopy since COPD patients can be atopic (most articles investigating COPD 
Table 1.-Definitions used for the different groups of smokers in this review

\begin{tabular}{lcccc}
\hline & $\begin{array}{c}\text { Chronic } \\
\text { symptoms }\end{array}$ & $\begin{array}{c}\text { FEV1/VC } \\
\% \text { pred }\end{array}$ & $\begin{array}{c}\text { FEV1 } \\
\% \text { pred }\end{array}$ \\
\cline { 3 - 4 } & & M & F & \\
\hline Nonsmoker & No & $>88$ & $>89$ & $>80$ \\
Smoker & No & $>88$ & $>89$ & $>80$ \\
Smoker with chronic bronchitis & Yes & $>88$ & $>89$ & $>80$ \\
Smoker with mild COPD & Yes & $<88$ & $<89$ & $>70$ \\
Smoker with moderate COPD & Yes & $<88$ & $<89$ & $50-69$ \\
Smoker with severe COPD & Yes & $<88$ & $<89$ & $\leqslant 50$ \\
\hline
\end{tabular}

FEV1: forced expiratory volume in one second; VC: vital capacity; M: male; F: female; COPD: chronic obstructive pulmonary disease; $\%$ pred: per cent predicted. ${ }^{\#}:$ chronic cough and phlegm for $\geqslant 3$ months $\cdot \mathrm{yr}^{-1}$ for $\geqslant 2$ yrs successively; ${ }^{\uparrow}$ : subject who has not smoked $>1$ cigarette $\cdot$ day $^{-1}$ for $1 \mathrm{yr}$, without chronic symptoms or airway obstruction.

patients exclude atopic individuals). Only articles investigating adult subjects (aged $>18$ yrs) were included.

Both longitudinal studies investigating smokers (with or without COPD) before and after smoking cessation and cross-sectional studies comparing smokers and exsmokers (with or without COPD) were selected. In the present review, a "smoker" is defined as someone who smokes and does not have chronic respiratory symptoms and airway obstruction. An "exsmoker" is defined as someone who quits smoking before the start of the study and refrains from smoking during the study, whereas a "quitter" is someone who smokes at the start of the study but quits smoking during or at the start of the study.

The structure of the present review is as follows. The effects of smoking cessation on respiratory symptoms, lung function, airway hyperresponsiveness (AHR), and pathological and inflammatory changes are described in separate sections. In each section, the effects of smoking cessation in smokers without chronic bronchitis or COPD are described first, followed by the effects of smoking cessation in smokers with chronic bronchitis or with different stages of COPD. Within each category, cross-sectional studies are described first and then, if available, longitudinal studies.

\section{Collection of data}

The MEDLINE search (1966-2002) consisted of various combination of the following keywords: smok*, smoking cessation, healthy smokers, exsmoker, chronic bronchitis, COPD, chronic obstructive pulmonary disease, respiratory symptoms, symptoms, cough, sputum, phlegm, shortness of breath, breathlessness, dyspnea, dyspnoea, lung, lung function, FEV1, decline in FEV1, bronchial hyperresponsiveness, airway hyperresponsiveness, BHR, AHR, AMP, adenosine5'-monophosphate, histamine, methacholine, inflammation, sputum, bronchial alveolar lavage, BAL, biopsy, exhaled nitric oxide and exhaled NO. Limits were set for the English language. Additional relevant studies were identified by manually searching the bibliographies of the articles retrieved.

\section{Respiratory symptoms}

\section{Subject without chronic respiratory symptoms}

The reported prevalences of intermittent cough, phlegm and wheeze are 5-21, 5-30 and $1-19 \%$, respectively, in exsmokers, and $10-40 \%$ for both cough and phlegm and $7-32 \%$ for wheeze in smokers [11-19]. In contrast, the prevalence of dyspnoea is similar between exsmokers and smokers (ranging 2-41\%), suggesting that the sensation of dyspnoea is either not reversible after smoking cessation, or due to factors other than lung disease. These cross-sectional studies suggest that respiratory symptoms improve after smoking cessation. However, these symptoms appear not to disappear as the prevalences of respiratory symptoms in exsmokers are reported as higher than or similar to those found in nonsmokers $[11-15,19,20]$.

Longitudinal studies are in line with the above crosssectional studies, showing that most intermittent symptoms (cough, phlegm and wheeze) decrease within 1-2 months after smoking cessation [21-27]. The prevalence of cough and wheeze decreases to that in nonsmokers, whereas the prevalence of phlegm remains slightly higher [21, 25]. Furthermore, symptoms are also less likely to develop later in life if smokers without chronic symptoms quit smoking [28, 29]. For instance, KRZYZANOWSKI et al. [28] showed that only 12\% of quitters versus $29 \%$ of persistent smokers developed cough or phlegm. The effect of smoking cessation on dyspnoea in this group of smokers is not uniform in different studies. Three studies, in which the duration of smoking cessation ranged 2-6 weeks to 1-12 yrs, showed no difference in the prevalence of dyspnoea after smoking cessation. In these studies, dyspnoea was defined as the feeling of "shortness of breath" or "having to stop for a breath while walking up a slight hill" or "walking with other people of the same age on the level ground" [25, 27, 28]. Another study suggested that 5 yrs of smoking cessation led to a small increase in dyspnoea when hurrying on the level or walking up a slight hill (41 to $52 \%$ ) [21]. An increase in body weight, as often occurs during smoking cessation, might explain the increase in dyspnoea, but this was not investigated in this study. Using yet another definition, "difficulty breathing", PETERSON et al. [30] showed that dyspnoea improved in 12 smokers after 1 and 18 months' smoking cessation, despite an increase in body weight.

The wide range of prevalences found among the available studies might be due to differences in the definition of symptoms, questionnaires used and/or study population, such as age, sex and geographical differences. This may also be an explanation for the differences in the effect of smoking cessation on dyspnoea. As mentioned above, dyspnoea in healthy smokers may be due to factors other than lung disease. In addition, it is unlikely that subjects without chronic respiratory symptoms experience the same degree of dyspnoea as COPD patients. Thus the severity of dyspnoea may be very low at the start of the studies, and hence improvement would be almost impossible after smoking cessation. Furthermore, the cumulative or daily cigarette consumption is not always mentioned, and, if it is, also varies between the studies. Nevertheless, this cannot explain all of the differences observed.

\section{Chronic bronchitis or chronic obstructive pulmonary disease}

In a cross-sectional study, patients with mild or moderate COPD (both smokers and exsmokers) reported cough and phlegm more often than patients with severe COPD (84 versus $68 \%$ ). Conversely, dyspnoea was more prevalent in patients with severe COPD $(80 \%)$ than in patients with mild $(33 \%)$ or moderate $(53 \%)$ COPD. The difference between smokers and exsmokers was not investigated separately in this study, but the group of patients with severe COPD $(n=38)$ contained relatively more exsmokers $(35 \%)$ than did the group of patients with mild or moderate COPD $(n=424 ; 20 \%)$ [31]. This 
might suggest that chronic cough and phlegm decrease after smoking cessation, in contrast to dyspnoea.

Very few longitudinal data are available with regard to the effect of smoking cessation on respiratory symptoms in smokers with chronic bronchitis or COPD. FRIEDMAN and SIEGELAUB [32] showed that chronic cough had disappeared after $1.5 \mathrm{yrs}$ in almost all smokers with chronic bronchitis who quitted smoking.

The Lung Health Study is a 5-yr follow-up study which assessed whether smoking cessation (and/or regular use of bronchodilators) ameliorated FEV1 decline in patients with mild-to-moderate COPD. This study included 5,887 smokers, aged 35-60 yrs, with an FEV1/forced $\mathrm{VC}$ of $<70 \%$ pred and FEV1 of $50-90 \%$ pred. The prevalences of chronic cough, chronic phlegm, wheeze ("day and night") and dyspnoea at the start of the study were 48, 43, 32 and $43 \%$, respectively [33]. The prevalence of these respiratory symptoms decreased by $>80 \%$ after $5 \mathrm{yrs}$ of smoking cessation. The greatest decrease occurred within the first year. In addition, the risk of developing respiratory symptoms de novo during the 5-yr follow-up was higher in persistent smokers $(28 \%)$ than in successful quitters $(4 \%)[2,34]$.

Although there is an improvement in symptoms after smoking cessation in smokers with chronic bronchitis and COPD, smoking cessation only induces complete normalisation when airflow limitation is absent.
Lung function (forced expiratory volume in one second)

\section{Subjects without chronic respiratory symptoms}

Cross-sectional studies have shown that FEV1 is lowest in individuals without chronic symptoms who smoke, highest in those who have never smoked and intermediate in exsmokers [20, 35-42]. One exception is the finding that exsmokers aged $>70$ yrs tend to have lower lung function than smokers of the same age. This can be attributed to a "healthy smoker" effect [43], i.e. smokers who are not troubled by their habit continue to smoke (so-called healthy smokers), whereas smokers who are troubled by their habit are more likely to quit smoking.

Most studies show a significant excess decline in FEV1 in smokers over nonsmokers, exsmokers and quitters $[6,8,16$, $25,39,44-56]$. Longitudinal data are shown in table 2 . There is considerable overlap between studies in the reported decline in FEV1 in smokers without chronic symptoms, exsmokers, quitters and nonsmokers. This large overlap cannot be explained by differences in age, baseline FEV1 or sex. However, it could be due to differences in the prevalence of respiratory symptoms and severity of bronchial hyperresponsiveness [15, 17, 46, 47, 56-58].

Prospective population studies have shown that smoking cessation in smokers without chronic symptoms slows the accelerated decline in lung function towards that observed in

Table 2.-Longitudinal data on lung function decline in smokers, exsmokers, quitters and nonsmokers without chronic respiratory symptoms

\begin{tabular}{|c|c|c|c|c|c|c|c|c|c|c|c|}
\hline \multirow[t]{2}{*}{ First author [ref.] } & \multirow[t]{2}{*}{$\begin{array}{l}\text { Subjects } \\
\text { n }\end{array}$} & \multirow[t]{2}{*}{ Sex } & \multirow[t]{2}{*}{$\mathrm{Age}^{\S} \mathrm{yrs}$} & \multicolumn{3}{|c|}{$\begin{array}{l}\text { Cumulative cigarette } \\
\text { consumption pack-yrs }\end{array}$} & \multirow[t]{2}{*}{$\begin{array}{c}\text { Follow-up } \\
\text { yrs }\end{array}$} & \multicolumn{4}{|c|}{$\begin{array}{l}\text { Decline in FEV1 } \\
\mathrm{mL} \cdot \mathrm{yr}^{-1}\end{array}$} \\
\hline & & & & $\mathrm{Sm}$ & Exsm & Quitter & & $\mathrm{Sm}$ & Exsm & Quitter & Nonsm \\
\hline BURCHFIEL [45] & $4451^{\text {बथ }}$ & M & 54 & & & & 6 & $34^{*}$ & 22 & $23^{\#}, 30^{f f}$ & 22 \\
\hline \multirow[t]{2}{*}{ SHERRILL [44] } & $477^{\bullet \uparrow}$ & M & $46(45-47)$ & 49 & 41 & & 7 & 17 & 27 & & 16 \\
\hline & & $\mathrm{F}$ & $46(41-52)$ & 43 & 19 & & 7 & 14 & 15 & & 12 \\
\hline BOSSE [46] & $850^{\text {ศथ }}$ & M & $42(39-44)$ & 21 & & 22 & 5 & 85 & & $57^{\#}$ & 53 \\
\hline \multirow[t]{2}{*}{ CAMILLI [47] } & $1705^{\circ \oplus}$ & M & 49 & 32 & 32 & 32 & 9.4 & $19^{+}$ & 4 & 6 & 6 \\
\hline & & $\mathrm{F}$ & 49 & 28 & 17 & 18 & 9.4 & $7^{+}$ & -0.7 & -4 & 0.4 \\
\hline \multirow[t]{2}{*}{ TASHKIN [25] } & $2401^{\text {बศ }}$ & M & 45 & 41 & 27 & 39 & 5 & $70^{+}$ & 52 & 62 & 56 \\
\hline & & $\mathrm{F}$ & 45 & 31 & 16 & 27 & 5 & $54^{+}$ & 38 & 38 & 42 \\
\hline \multirow[t]{2}{*}{ SHERMAN [16] } & $3948^{\bullet \oplus}$ & M & 48 & 32 & 24 & & 12 & $44^{+}$ & 35 & & 33 \\
\hline & & $\mathrm{F}$ & 49 & 22 & 12 & & 12 & $34^{+}$ & 27 & & 28 \\
\hline \multirow[t]{2}{*}{ XU [49] } & $4554^{\oplus \oplus}$ & M & $15-54$ & & & & 24 & $19^{*}, 26^{*}, 33^{*,++}$ & 20 & $6^{\#}$ & 6 \\
\hline & & $\mathrm{F}$ & $15-54$ & & & & 24 & $15^{*}, 20^{*}, 30^{*,++}$ & 19 & $3^{\#}$ & 15 \\
\hline \multirow[t]{2}{*}{ XU [39] } & $5572^{\bullet \oplus}$ & M & $25-78$ & & & & 6 & $53^{+}$ & 34 & $41^{\#}$ & 38 \\
\hline & & $\mathrm{F}$ & $25-78$ & & & & 6 & $38^{+}$ & 30 & $29^{\#}$ & 29 \\
\hline \multirow[t]{4}{*}{ LANGE [8] } & $7764^{\text {बथ }}$ & M & $<55$ & & & & 5 & $22,42^{\S \S}$ & 27 & $17,36^{\S \S}$ & 21 \\
\hline & & & $>55$ & & & & 5 & $52,56^{\S \S}$ & 36 & $11,43^{\S \S}$ & 34 \\
\hline & & $\mathrm{F}$ & $<55$ & & & & 5 & $17,30^{\S \S}$ & 18 & $15,9^{\S \S}$ & 13 \\
\hline & & & $>55$ & & & & 5 & $39,48^{\S \S}$ & 32 & $28, \S \S$ & 32 \\
\hline TOWNSEND [55] & 4926 & M & 47 & & & & $6-7$ & $59^{+}$ & 44 & 50 & 51 \\
\hline \multirow[t]{2}{*}{ PELKONEN $[51]^{f}$} & $411^{\text {बथ }}$ & M & 47 & & & & 30 & $52^{+}$ & 36 & 40 & 35 \\
\hline & $1007^{\bullet \oplus}$ & M & 49 & 27 & 18 & 25 & 15 & $66^{+}$ & 49 & 56 & 46 \\
\hline \multirow[t]{2}{*}{ KRZYZANOWSKI [52] } & $1824^{\pi \oplus}$ & M & $40(19-70)$ & & & & 13 & $60 *$ & 50 & 68 & 47 \\
\hline & & $\mathrm{F}$ & $40(19-70)$ & & & & 13 & 42 & 38 & 37 & 38 \\
\hline \multirow[t]{4}{*}{ KRZYZANOWSKI [56] } & $640^{\oplus \oplus}$ & M & 45 & & & & 12 & 11.7 & & 6.8 & 6.3 \\
\hline & & $\mathrm{F}$ & 48 & & & & 12 & 10.5 & & 1.6 & 7.6 \\
\hline & $1738^{\text {๓ศף }}$ & M & 40 & & & & 12 & 14 & & 16.5 & 8.7 \\
\hline & & $\mathrm{F}$ & 40 & & & & 12 & 6.6 & & 1.4 & 6.1 \\
\hline TAYLOR [53] & $227^{\bullet \oplus \oplus}$ & M & $51-61$ & & & & 7.5 & $11^{+}$ & 8 & & 6.6 \\
\hline
\end{tabular}

FEV1: forced expiratory volume in one second; Sm: smokers without chronic respiratory symptoms; Exsm: exsmokers who quitted smoking before the start of the study; Quitter: healthy smoker at start of study, exsmoker at end of study; Nonsm: nonsmoker; M: male; F: female. ${ }^{\S}$ : mean, range or mean (range); ${ }^{f}$ : part of population followed for $30 \mathrm{yrs}(\mathrm{n}=411)$, duration of smoking rather than cumulative cigarette consumption described and FEV0.75 rather than FEV1 measured; ${ }^{\# \#}$ : two populations studied: Tucson, AZ, USA (n=640), and Cracow, Poland (n=1,738); ${ }^{\oplus \uparrow}$ : general population

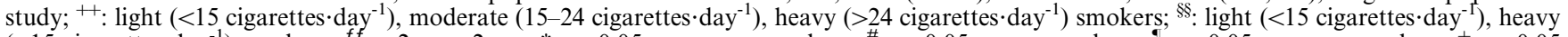
$\left(>15\right.$ cigarettes $\cdot$ day $\left.^{-1}\right)$ smokers; ${ }^{f f}:>2$ ys, $<2$ yrs. *: $\mathrm{p}<0.05$ versus nonsmokers; ${ }^{\#}: \mathrm{p}<0.05$ versus smokers; ${ }^{\uparrow}: \mathrm{p}<0.05$ versus exsmokers; ${ }^{+}: \mathrm{p}<0.05$ versus all other groups. 
nonsmokers (table 2) $[8,25,45-47,51,52,55,56]$. The decline in FEV1 normalises 2 yrs after smoking cessation [45, 55]. However, in one study, a more rapid decline in FEV1 was found in exsmokers than in nonsmokers $\left(20\right.$ and $6 \mathrm{~mL} \cdot \mathrm{yr}^{-1}$, respectively). The decline in FEV1 in quitters was similar to that in nonsmokers in this study [49]. Only one longitudinal study, using a small number of subjects, showed that FEV1 improved after smoking cessation [59], but most studies do not show this $[8,24,26,30,39,45,47,49,51,55,60,61]$. A probable explanation is the already normal lung function in these participants before smoking cessation.

Several studies in smaller numbers of subjects $(n=10-50)$ have investigated the effects of smoking cessation on uneven ventilation and small airway closure using the single-breath nitrogen-washout test. In this test, uneven ventilation is reflected by the slope of phase III (change in nitrogen concentration $\left(\Delta \mathrm{N}_{2}\right)$ ), and small airway closure by closing volume $(\mathrm{CV}) / \mathrm{VC}$ and closing capacity $(\mathrm{CC}) /$ total lung capacity (TLC). Although smokers without chronic symptoms exhibited normal FEV1, many showed higher $\Delta \mathrm{N}_{2}, \mathrm{CV} / \mathrm{VC}$ and CC/TLC than nonsmokers. This could not be attributed to any difference in other variables such as cumulative cigarette consumption, age or other lung function variables [24, 59]. Since a higher CV and CC indicate earlier small airway closure at end-expiration, this might indicate that the small airways are already changed in these smokers. This is supported by the results of NIEWOEHNER et al. [5], who found inflammation in the small airways of smokers without chronic symptoms. Smoking cessation improved $\Delta \mathrm{N}_{2}, \mathrm{CV} / \mathrm{VC}$ and CC/TLC, indicating that these smoke-induced changes are probably reversible in this population $[24,25,59,62]$.

\section{Chronic bronchitis or chronic obstructive pulmonary disease}

Table 3 presents a literature overview of the effect of smoking cessation on lung function (FEV1) decline in patients with chronic bronchitis or COPD. FLETCHER and PETO [63] investigated males with mild airway obstruction and showed that the accelerated decline in FEV1 in exsmokers was slower than that in smokers ( 37 and $62 \mathrm{~mL} \cdot \mathrm{yr}^{-1}$, respectively). In addition, Postma et al. [67] showed that smoking cessation in smokers with moderate COPD reduced the accelerated decline in FEV1 by $\sim 50 \%$, from 85 to $49 \mathrm{~mL} \cdot \mathrm{yr}^{-1}$. The results of the Lung Health Study in mild-to-moderate COPD patients showed a similar reduction in the $5 \mathrm{yrs}$ following their date of smoking cessation, i.e. $63 \mathrm{~mL} \cdot \mathrm{yr}^{-1}$ in persistent smokers and $34 \mathrm{~mL} \cdot \mathrm{yr}^{-1}$ in quitters [3, 64-66, 71] (fig. 1). During the first year after smoking cessation, FEV1 improved by $57 \mathrm{~mL}$ in quitters, whereas it fell by $32 \mathrm{~mL}$ in persistent smokers [64]. After 11 yrs of follow-up, the decline in FEV1 in quitters was $30 \mathrm{~mL} \cdot \mathrm{yr}^{-1}$ for males and $22 \mathrm{~mL} \cdot \mathrm{yr}^{-1}$ for females, whereas, in continuous smokers, the decline was $66 \mathrm{~mL} \cdot \mathrm{yr}^{-1}$ and $54 \mathrm{~mL} \cdot \mathrm{yr}^{-1}$, respectively [71].

Decline in FEV1 is strongly related to cumulative cigarette consumption and severity of pre-existent bronchial hyperresponsiveness in smokers with COPD [65, 67]. Decline in FEV1 is also related to the number of cigarettes smoked: heavy smokers with mild-to-moderate COPD showed a greater decline than light smokers, and these heavy smokers showed

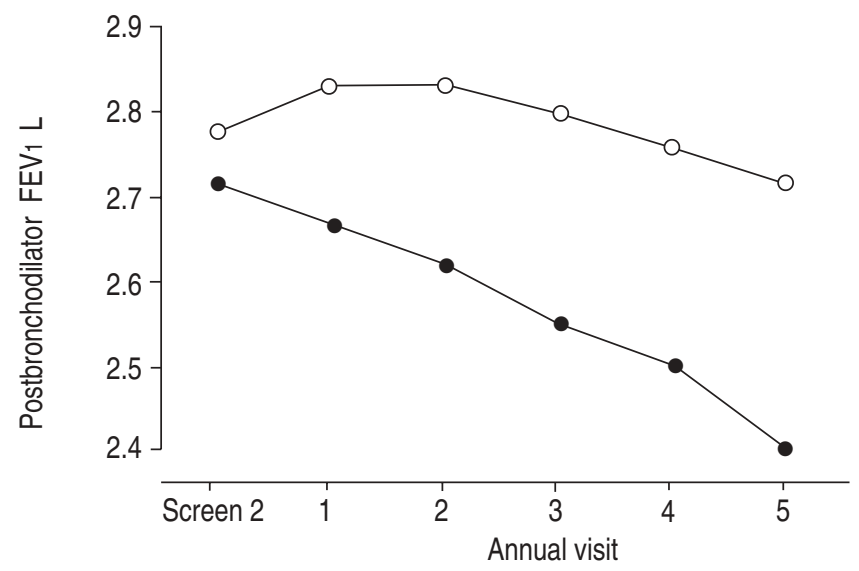

Fig. 1. - Effect of smoking cessation $(\bigcirc$ : persistent smoking cessation; -: continued smoking) on postbronchodilator forced expiratory volume in one second (FEV1) decline. From [64].

Table 3. - Effects of smoking cessation on decline in lung function in smokers with chronic bronchitis (CB) or chronic obstructive pulmonary disease (COPD)

\begin{tabular}{|c|c|c|c|c|c|c|c|c|c|c|c|}
\hline \multirow[t]{2}{*}{ First author [ref.] } & \multirow[t]{2}{*}{$\begin{array}{l}\text { Subjects } \\
\mathrm{n}\end{array}$} & \multirow[t]{2}{*}{ Sex } & \multirow[t]{2}{*}{ Age yrs } & \multirow[t]{2}{*}{$\mathrm{CB} / \mathrm{COPD}$} & \multicolumn{3}{|c|}{$\begin{array}{l}\text { Cumulative cigarette } \\
\text { consumption pack-yrs }\end{array}$} & \multirow[t]{2}{*}{$\begin{array}{l}\text { Follow-up } \\
\text { yrs }\end{array}$} & \multicolumn{3}{|c|}{$\begin{array}{l}\text { Decline in FEV1 } \\
\mathrm{mL} \cdot \mathrm{yr}^{-1}\end{array}$} \\
\hline & & & & & $\mathrm{Sm}$ & Exsm & Quitter & & $\mathrm{Sm}$ & Exsm & Quitter \\
\hline COMSTOCK [21] & 670 & M & $40-59$ & $\mathrm{CB}^{\#}$ & & & & 5 & 82 & & 34 \\
\hline FLETCHER [63] & $792^{\bullet}$ & M & $50-59$ & $\begin{array}{l}\text { Mild } \\
\text { None }\end{array}$ & & & & $\begin{array}{l}8 \\
8\end{array}$ & $\begin{array}{l}62,80^{+} \\
42,55^{+}\end{array}$ & $\begin{array}{l}37 \\
30\end{array}$ & \\
\hline ANTHONISEN $[3,64]$ & 5887 & $\mathrm{M} / \mathrm{F}$ & 48 & Mild-moderate & 40 & & & 5 & 63 & & $34^{\S}$ \\
\hline SCANLON [65] & 3818 & $\mathrm{M} / \mathrm{F}$ & 49 & Mild-moderate & 41 & & 40 & 5 & 62 & & 31 \\
\hline MURRAY [66] & 5887 & $\mathrm{M} / \mathrm{F}$ & 48 & Mild & $42,36^{f}$ & & $42,36^{f}$ & 5 & $1.2 \%$ pred & & $0.33 \%$ pred \\
\hline POSTMA [67] & $81^{\# \#}$ & $\mathrm{M} / \mathrm{F}$ & 48 & Moderate-severe & 40 & & & $2-21$ & 85 & & $49^{\operatorname{l|} \mid}$ \\
\hline Postma [68] & $81^{++}$ & $\mathrm{M}$ & 48 & Moderate & 40 & & & $2.8-20$ & 85 & 49 & \\
\hline BARTER [69] & $34^{\S \S}$ & M & 56 & Mild & & & & 5 & 56 & 16 & \\
\hline HUGHES [70] & $56^{f f}$ & M & 54,57 & Mild-moderate & 37 & 35 & & $3-13$ & 54 & 16 & \\
\hline ANTHONISEN [71] & 4517 & $\begin{array}{c}\mathrm{M} \\
\mathrm{F}\end{array}$ & 61 & Mild-moderate & & & & 11 & $\begin{array}{l}66 \\
54\end{array}$ & & $\begin{array}{l}30 \\
22\end{array}$ \\
\hline LEADER [72] & $25^{\# \# \#}$ & $\mathrm{M} / \mathrm{F}$ & 50 & Mild-moderate & 61 & & 71 & 0,8 and 28 weeks & & & 0 \\
\hline
\end{tabular}

FEV1: forced expiratory volume in one second; Sm: smokers; Exsm: exsmokers who quitted smoking before the start of the study; Quitter: someone who quits smoking at start of study and is still not smoking at end of study; M: male; F: female; $\%$ pred: per cent predicted. ${ }^{\#}: 90 \%$ of the smokers had

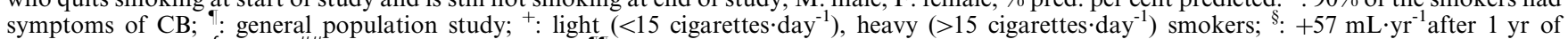
smoking cessation; ${ }^{f}: \mathrm{M}, \mathrm{F} ;{ }^{\# \#}: 59$ smokers, 22 quitters; ${ }^{\top}$ : quitters defined as those who smoked at the start of the study but quitted smoking at some point during the study and did not start smoking again; ${ }^{++}$: FEV1 $63 \%$ pred without steroids; ${ }^{\text {; }}$ : five exsmokers; ${ }^{f f}: 37$ smokers, 19 exsmokers; ${ }^{\# \# \#: ~} 18$ smokers, seven quitters. 
greater FEV1 improvement after smoking cessation than light smokers [65].

\section{Airway hyperresponsiveness}

\section{Subjects without chronic respiratory symptoms}

The prevalence of AHR to histamine has been reported to be similar in smokers and exsmokers without chronic symptoms [15, 53, 73], whereas the prevalence of AHR to methacholine is higher in smokers than in exsmokers (table 4) $[54,74,75,77]$. This suggests that AHR to histamine is less reversible after smoking cessation than that to methacholine. This is, however, as yet unresolved since RIJCKEN et al. [15] found no differences in the prevalence of AHR to histamine in smokers, exsmokers and nonsmokers, whereas TAYLOR et al. [53] found a higher prevalence of AHR to histamine in exsmokers than in nonsmokers. The prevalence of AHR to methacholine has been reported to be similar in exsmokers and nonsmokers [54, 74-77], suggesting at least a real improvement in AHR to methacholine after smoking cessation.

Only three studies have investigated the longitudinal effects of smoking cessation on AHR in smokers without chronic symptoms (table 5), predominantly showing that AHR to methacholine or carbachol does not change after smoking cessation $[23,27,61]$. However, the number of subjects investigated was small $(\mathrm{n}=10-17)$, and most individuals had no AHR at the start of the study, which made it virtually impossible to find a significant improvement after smoking cessation.

LIM et al. [73] showed that the severity of AHR to histamine deteriorated in smokers without chronic symptoms who continued smoking: the provocative concentration of histamine causing a $20 \%$ fall in FEV1 changed significantly from 7.1 to $3.3 \mathrm{mg} \cdot \mathrm{mL}^{-1}$ over 4 yrs. In contrast, AHR did not change (from 6.7 to $6.0 \mathrm{mg} \cdot \mathrm{mL}^{-1}$ ) in subjects who refrained from smoking. Taken together, this suggests that smoking cessation would prevent future deterioration in AHR, although it does not lead to improvement.

\section{Chronic bronchitis and chronic obstructive pulmonary disease}

Cross-sectional studies investigating AHR in smokers and exsmokers with chronic bronchitis or COPD are presented in

Table 4. - Cross-sectional data on airway hyperresponsiveness (AHR) in smokers, exsmokers and nonsmokers without chronic respiratory symptoms

\begin{tabular}{|c|c|c|c|c|c|c|c|}
\hline $\begin{array}{l}\text { First author } \\
\text { [ref.] }\end{array}$ & $\begin{array}{l}\text { Subjects } \\
\mathrm{n}\end{array}$ & Sex & Age yrs & Method & $\begin{array}{c}\text { AHR response } \\
\% \%\end{array}$ & Results & Comments \\
\hline \multirow[t]{3}{*}{ KABIRAJ [54] } & $18 \mathrm{Nsm}$ & M & 48 & $\begin{array}{l}\text { FEV1 fall after } \\
10 \mathrm{mg} \cdot \mathrm{mL}^{-1} \mathrm{MCh}\end{array}$ & 9.8 & $\mathrm{Sm}>\mathrm{Exsm}=\mathrm{Nsm}$ & $\begin{array}{l}\text { Atopy unk; symptoms } \\
\text { in both Sm and Exsm, } \\
\text { but not in all }\end{array}$ \\
\hline & 20 Exsm & M & 48 & & 9.5 & & \\
\hline & $22 \mathrm{Sm}$ & M & 48 & & 19.5 & & \\
\hline \multirow[t]{3}{*}{ CERVERI [74] } & $295 \mathrm{Nsm}$ & $\mathrm{M} / \mathrm{F}$ & $39(15-64)$ & PD15 <7.9 mg MCh & 11 & $\mathrm{Sm}>\mathrm{Exsm}=\mathrm{Nsm}$ & All asymptomatic and NA \\
\hline & 50 Exsm & $\mathrm{M} / \mathrm{F}$ & & & 15 & & \\
\hline & $70 \mathrm{Sm}$ & $\mathrm{M} / \mathrm{F}$ & & & $43^{+}$ & & \\
\hline \multirow[t]{3}{*}{ PAOLETTI $[75]^{\top}$} & 693 Nsm & $\mathrm{M} / \mathrm{F}$ & $8-73$ & $\mathrm{PD} 20<4.8 \mathrm{mg} \mathrm{MCh}$ & $34,23^{\S}$ & $\mathrm{Sm}>$ Exsm=Nsm $(\mathrm{F})$ & NI \\
\hline & 369 Exsm & $\mathrm{M} / \mathrm{F}$ & & & $31,21^{\S}$ & $\mathrm{Sm}=\mathrm{Exsm}=\mathrm{Nsm}(\mathrm{M})$ & \\
\hline & $496 \mathrm{Sm}$ & $\mathrm{M} / \mathrm{F}$ & & & $40,25^{\S}$ & & \\
\hline \multirow[t]{3}{*}{ SUNYER [76] } & 387 Nsm & $\mathrm{M} / \mathrm{F}$ & $32(20-44)$ & $\begin{array}{l}\mathrm{PC} 20<100 \mathrm{mg} \cdot \mathrm{mL}^{-1} \\
\mathrm{MCh}\end{array}$ & $13,5,25,21^{\# \#}$ & $\mathrm{Sm}>\mathrm{Exsm}=\mathrm{Nsm}(\mathrm{NA})$ & \\
\hline & 163 Exsm & $\mathrm{M} / \mathrm{F}$ & & & $14,8,14,31^{\# \#}$ & $\mathrm{Sm}=\mathrm{Exsm}=\mathrm{Nsm}(\mathrm{A})$ & \\
\hline & $619 \mathrm{Sm}^{f}$ & $\mathrm{M} / \mathrm{F}$ & & & $24,18,20,18^{\# \#}$ & & \\
\hline \multirow[t]{3}{*}{ SPARROW [77] } & $129 \mathrm{Nsm}$ & $\mathrm{M}$ & $50-59$ & $\mathrm{PD} 20<8.6 \mu \mathrm{mol} \mathrm{MCh}$ & 9.3 & $\mathrm{Sm}>\mathrm{Exsm}=\mathrm{Nsm}$ & $\begin{array}{l}\text { Age range selected } \\
\qquad(\mathrm{n}=914 \text { in study })\end{array}$ \\
\hline & 172 Exsm & & & & 8.7 & & \\
\hline & $66 \mathrm{Sm}$ & & & & 22.7 & & \\
\hline \multirow[t]{3}{*}{ BURNEY [78] } & $259 \mathrm{Nsm}$ & $\mathrm{M} / \mathrm{F}$ & 41 & $\mathrm{PD} 20<8 \mu \mathrm{mol} \mathrm{HA}$ & 10 & $\mathrm{Sm}>\mathrm{Exsm}=\mathrm{Nsm}$ & \\
\hline & 116 Exsm & $\mathrm{M} / \mathrm{F}$ & & & 12 & & \\
\hline & $136 \mathrm{Sm}$ & $\mathrm{M} / \mathrm{F}$ & & & 24 & & \\
\hline \multirow[t]{3}{*}{ TAYLOR [53] } & $39 \mathrm{Nsm}$ & $\mathrm{M}$ & $51-61$ & $\mathrm{PC} 20<16 \mathrm{mg} \cdot \mathrm{mL}^{-1} \mathrm{HA}$ & 5 & $\mathrm{Sm}=\mathrm{Exsm}>\mathrm{Nsm}$ & NI \\
\hline & 71 Exsm & M & & & 24 & $\mathrm{Sm}=\mathrm{Exsm}^{\boldsymbol{9}}$ & \\
\hline & $117 \mathrm{Sm}$ & M & & & 29 & & \\
\hline \multirow[t]{2}{*}{ LIM [73] } & 16 Exsm & M & 53 & $\mathrm{PC} 20 \mathrm{HA} \mathrm{mg} \cdot \mathrm{mL}^{-1}$ & 6.7 & $\mathrm{Sm}=\mathrm{Exsm}$ & NI \\
\hline & $27 \mathrm{Sm}$ & $\mathrm{M}$ & 59 & & 7.1 & & \\
\hline \multirow[t]{3}{*}{ XU [79 $]^{\bullet}$} & Nsm & $\mathrm{M} / \mathrm{F}$ & $>8$ & $\mathrm{PC} 10<8 \mathrm{mg} \cdot \mathrm{mL}^{-1} \mathrm{HA}$ & 16 & $\mathrm{Sm}=\mathrm{Nsm}$ & NI \\
\hline & Exsm & & & & 18 & & \\
\hline & Sm (2684) & & & & $20,33^{++}$ & & \\
\hline \multirow[t]{3}{*}{ RIJCKEN [15] } & $574 \mathrm{Nsm}$ & $\mathrm{M} / \mathrm{F}$ & 32.7 & $\mathrm{PC} 10<16 \mathrm{mg} \cdot \mathrm{mL}^{-1} \mathrm{HA}$ & 24 & $\mathrm{Sm}=\mathrm{Exsm}=\mathrm{Nsm}$ & NI \\
\hline & 252 Exsm & $\mathrm{M} / \mathrm{F}$ & & & 18 & & \\
\hline & $1013 \mathrm{Sm}$ & $\mathrm{M} / \mathrm{F}$ & & & 28 & & \\
\hline
\end{tabular}

Nsm: nonsmoker; Sm: smokers without chronic respiratory symptoms; Exsm: exsmoker; M: male; F: female; FEV1: forced expiratory volume in one second; MCh: methacholine; unk: unknown; PD15: provocative dose of drug causing a 15\% fall in FEV1; NA: nonatopic; PD20: provocative dose of drug causing a 20\% fall in FEV1; NI: no information about atopy or symptoms; PC20: provocative concentration of drug causing a $20 \%$ fall in FEV1; A: atopic; HA: histamine; PC10: provocative concentration of drug causing a $10 \%$ fall in FEV1. ${ }^{\#}$ : severity or prevalence (see $M e t h o d$ column); general population study; ${ }^{+}: 27 \%$ heavy plus $16 \%$ moderate (<18 pack-yrs) smokers; ${ }^{\S}$ : F, M; ${ }^{f}$ : cumulative cigarette consumption 15 pack-yrs; \#\#: NA-F, NA-M, A-F, A-M; ${ }^{\bullet \uparrow}$ : subjects aged $<35$ yrs $(n=30) ;{ }^{++}:<24$ cigarettes $\cdot$ day $^{-1},>25$ cigarettes $^{*}$ day $^{-1}$. 
Table 5.-Effect of smoking cessation (SC) on airway hyperresponsiveness (AHR) in smokers without chronic respiratory symptoms

\begin{tabular}{|c|c|c|c|c|c|c|c|c|c|c|}
\hline \multirow{2}{*}{$\begin{array}{l}\text { First author } \\
\text { [ref.] }\end{array}$} & \multirow{2}{*}{$\begin{array}{c}\text { Subjects } \\
\mathrm{n}\end{array}$} & \multirow[t]{2}{*}{ Sex } & \multirow{2}{*}{$\begin{array}{l}\text { Age } \\
\text { yrs }\end{array}$} & \multirow{2}{*}{$\begin{array}{c}\text { Cumulative } \\
\text { cigarette } \\
\text { consumption } \\
\text { pack-yrs }\end{array}$} & \multirow[t]{2}{*}{ Sympt } & \multirow[t]{2}{*}{ SC period } & \multirow[t]{2}{*}{ Method } & \multicolumn{3}{|c|}{$\mathrm{AHR}^{\#}$} \\
\hline & & & & & & & & $\begin{array}{l}\text { Before } \\
\text { SC } \%\end{array}$ & $\begin{array}{l}\text { After } \\
\text { SC } \%\end{array}$ & $\begin{array}{c}\text { SC } \\
\text { effect }\end{array}$ \\
\hline BUCZKO [23] & 17 & $\mathrm{M} / \mathrm{F}$ & 35 & 20 & $14 / 17$ & $99 \pm 43$ days & MCh TC & $1.0 \mathrm{mg} \cdot \mathrm{mL}^{-1}$ & $1.6 \mathrm{mg} \cdot \mathrm{mL}^{-1}$ & None \\
\hline SIMONSSON [61] & 10 & $\mathrm{M} / \mathrm{F}$ & 42 & 25 & Some & $\begin{array}{r}1 \text { week; } 1,6 \text {, } \\
12 \text { months }\end{array}$ & $\begin{array}{l}>15 \% \text { FEV } 1 \\
\text { fall }\left(\mathrm{MCh}^{+}\right)\end{array}$ & 30 & $20^{\S}$ & None \\
\hline ISRAEL [27] & 10 & $\mathrm{M} / \mathrm{F}$ & 36 & 20 & Some & 2,6 months & $\begin{array}{l}\text { PD35 } \\
\text { PD20 }\end{array}$ & $\begin{array}{l}20 \\
60\end{array}$ & $\begin{array}{l}40,50^{f} \\
60,70^{f}\end{array}$ & None \\
\hline
\end{tabular}

Sympt: symptoms (occasional cough or sputum production); M: male; F: female; MCh: methacholine; TC: threshold concentration (baseline volume $40 \%$ vital capacity above residual volume minus 2.8 SD); FEV1: forced expiratory volume in one second; PD35: provocative dose of carbachol (various doses used) causing a 35\% fall in specific airway conductance; PD20: provocative dose of carbachol (various doses used) causing a $20 \%$ fall in FEV1. ${ }^{\#}$ : severity or prevalence (see Method column); ${ }^{\oplus}$ : mean $\pm \mathrm{SD} ;{ }^{+}$: various concentrations used; ${ }^{\S}$ : at 12 months; ${ }^{f}$ : at 2 months, 6 months.

table 6. The severity of AHR to histamine or methacholine is similar in smokers and exsmokers with moderate COPD [81, 82]. This suggests that AHR to histamine and methacholine does not revert to normal levels after smoking cessation in COPD, which could be due to either ongoing inflammation or irreversible structural changes in the lung. In contrast, hyperresponsiveness to adenosine- $5^{\prime}$-monophosphate is more severe in current smokers than in exsmokers with moderate COPD, even when AHR to methacholine is similar between these groups [81]. These cross-sectional data suggest that AHR to adenosine-5'-monophosphate improves after smoking cessation, possibly as a consequence of a decrease in the number of mast cells in the lung [85].

The above cross-sectional data are not in line with the 5-yr follow-up data of the Lung Health Study [86]. Continuous smokers showed a more than three-fold deterioration in AHR to methacholine compared to sustained quitters. Interestingly, the authors also showed that a considerable degree of the effect of smoking on AHR could be accounted for by the induced changes in FEV1 [86].

\section{Pathological and inflammatory changes in the lungs}

\section{Subjects without chronic respiratory symptoms}

The effect of smoking cessation on pathological changes and inflammation in smokers without chronic respiratory symptoms has not been extensively investigated. Only two studies have assessed pathological changes in smokers and exsmokers without chronic symptoms undergoing surgical treatment for a lung tumour [87, 88]. Goblet cell hyperplasia was observed remarkably less in these exsmokers. Squamous metaplasia was not different in the central airways, but tended to be less abundant in the peripheral airways of exsmokers

Table 6. - Cross-sectional data on airway hyperresponsiveness (AHR) in smokers and exsmokers with chronic bronchitis (CB) or chronic obstructive pulmonary disease (COPD)

\begin{tabular}{|c|c|c|c|c|c|c|c|}
\hline $\begin{array}{l}\text { First author } \\
\text { [ref.] }\end{array}$ & Subjects $^{\#} \mathrm{n}$ & $\begin{array}{l}\text { Age } \\
\text { yrs }\end{array}$ & $\begin{array}{l}\text { Cumulative } \\
\text { cigarette } \\
\text { consumption } \\
\text { pack-yrs }\end{array}$ & $\mathrm{CB} / \mathrm{COPD}$ & Method & AHR response & Results \\
\hline TASHKIN [80] & $5877 \mathrm{Sm}$ & 49 & 41 & Mild COPD & $\begin{array}{l}\mathrm{PC} 20<25 \mathrm{mg} \cdot \mathrm{mL}^{-1} \\
\mathrm{MCh} \%\end{array}$ & $59,85^{\bullet}$ & \\
\hline \multirow[t]{3}{*}{$\begin{array}{l}\text { OOSTERHOFF } \\
{[81]}\end{array}$} & $12 \mathrm{Sm}$ & 57 & 20 & \multirow[t]{3}{*}{ Moderate COPD } & \multirow[t]{4}{*}{$\begin{array}{l}\mathrm{PC} 20 \mathrm{MCh} / \mathrm{AMP} \\
\mathrm{mg} \cdot \mathrm{mL}^{-1}\end{array}$} & $>16,>320^{+}$ & $\begin{array}{l}\mathrm{Sm}<\mathrm{Sm} \mathrm{COPD}=\mathrm{Exsm} \\
\mathrm{COPD}(\mathrm{MCh})\end{array}$ \\
\hline & $19 \mathrm{Sm}$ COPD & 60 & 13 & & & $0.35,7.2^{+}$ & $\begin{array}{l}\mathrm{Sm}<\text { Exsm } \mathrm{COPD}<\mathrm{Sm} \\
\mathrm{COPD}(\mathrm{AMP})\end{array}$ \\
\hline & 11 Exsm COPD & 63 & & & & $0.5,58^{+}$ & \\
\hline \multirow[t]{4}{*}{ POSTMA [82] } & $5 \mathrm{Sm}$ & 53 & 24 & \multirow[t]{3}{*}{$\begin{array}{l}\text { Moderate/severe } \\
\text { COPD }\end{array}$} & & No AHR & $\mathrm{Sm}<\mathrm{Sm}$ COPD \\
\hline & 5 Exsm & & 15 & & & No AHR & Exsm $<$ Sm COPD \\
\hline & 14 Sm COPD & 57 & 35 & & $\mathrm{PC} 20 \mathrm{HA} \mathrm{mg} \cdot \mathrm{mL}^{-1}$ & 6.73 & $\begin{array}{l}\text { Sm COPD=Exsm } \\
\text { COPD }\end{array}$ \\
\hline & 14 Exsm COPD & 55 & 26 & & & 5.58 & \\
\hline BAHOUS [83] & $\begin{array}{l}24 \mathrm{Sm} \text { COPD/CB } \\
4 \mathrm{Exsm} \mathrm{COPD} / \mathrm{CB}\end{array}$ & 50 & 37 & $\begin{array}{l}\mathrm{CB}(\mathrm{n}=14), \text { mild } \\
\mathrm{COPD}(\mathrm{n}=4), \\
\text { moderate COPD } \\
(\mathrm{n}=10)\end{array}$ & $\begin{array}{c}\mathrm{PC} 20<8 \mathrm{mg} \cdot \mathrm{mL}^{-1} \\
\text { HA/MCh } \% \$\end{array}$ & $\begin{array}{c}\text { CB 7, COPD } \\
100\end{array}$ & $\mathrm{Sm} \mathrm{CB}<\mathrm{Sm}$ COPD \\
\hline \multirow{2}{*}{$\begin{array}{l}\text { WOOLCOCK } \\
{[84]}\end{array}$} & $10 \mathrm{Sm}$ COPD & 56 & 53 & Mild COPD & PD20 MCh $\mu \mathrm{mol}$ & $1.0-10$ & Nsm $<$ Sm COPD \\
\hline & $2 \mathrm{Nsm}$ & & & COPD $(n=8)$ & PD20 HA $\mu \mathrm{mol}$ & $0.5-5.9$ & \\
\hline
\end{tabular}

Sm: smoker; Exsm: exsmoker; Nsm: nonsmoker; PC20: provocative concentration of drug causing a $20 \%$ fall in forced expiratory volume in one second (FEV1); MCh: methacholine; AMP: adenosine 5'-monophosphate; HA: histamine; PD20: provocative dose of drug causing a $20 \%$ fall in FEV1. \#: male and female subjects in all studies; ${ }^{\uparrow}$ : males, females; ${ }^{+}$: MCh, AMP; : response identical for HA and MCh. 
compared to smokers. Gland size and smooth muscle mass in the peripheral and central airways were similar in both groups. No differences were found in the amount of fibrosis in the peripheral airways or pigment deposition in the airway wall and the number of destroyed alveoli. Apparently, such pathological changes are not or less reversible after smoking cessation, in contrast to goblet cell hyperplasia.

The aforementioned studies [87, 88] also assessed inflammation, but found no differences in the intensity of inflammation in central and peripheral airways. Other crosssectional studies, using indirect and direct measures of airway inflammation or more specific immunological techniques, have shown different results. In blood, leukocyte counts are lower in exsmokers than in smokers, suggesting improvement [32, 89-92] but not always normalisation [89] after smoking cessation. In exsmokers, the percentage of CD4+ lymphocytes is lower than in smokers and normalises after $2 \mathrm{yrs}$ of smoking cessation [90, 93]. In addition, the percentage of natural killer cells is higher in exsmokers than in smokers [93, 94]. In exhaled air, exsmokers show similar nitric oxide levels to nonsmokers, in contrast to the lower levels measured in smokers [95-100]. In sputum, interleukin (IL)-8 levels are similar in exsmokers and smokers [101], but remain higher than in nonsmokers [102, 103], suggesting that proinflammatory activity might not change after smoking cessation. Only one bronchoalveolar lavage fluid (BALF) study compared exsmokers (age 62 yrs, $n=6$ ), smokers (age 49 yrs, $n=14$ ) and nonsmokers (age 48 yrs, $n=15$ ). The percentages of all cells in BALF were similar between smokers and exsmokers. The number of neutrophils, however, tended to be lower in exsmokers than in smokers, but remained higher than in nonsmokers. In addition, the number of macrophages was lower in exsmokers than in smokers, and similar to the number of macrophages in nonsmokers. The same study reported that the concentration of monocyte chemotactic protein-1 (MCP-1), an important chemoattractant for macrophages, was higher in smokers than in exsmokers and nonsmokers, with no difference between the latter groups. The concentration of macrophage inhibitory protein-1b, another monocyte chemoattractant, in BALF was similar between the groups. Thus, after smoking cessation, the higher number of macrophages and MCP-1 levels seem to normalise, whereas the number of neutrophils does not [104].

A few studies have assessed the effect of smoking cessation on inflammation in smokers without chronic respiratory symptoms in a longitudinal way (table 7). Endobronchial findings showed that macroscopic signs of chronic bronchitis (oedema, erythema and mucus) decreased within 3 months after smoking cessation, and totally disappeared after 6 months [115]. Exhaled NO levels increased almost to normal values within 1 week of smoking cessation, suggesting that the smoke-induced inhibition of inducible nitric oxide synthase production by epithelial cells is reversible [105].

The number of blood leukocytes fell almost immediately after smoking cessation, the largest effect occurring within the first 9 months $[89,106,107]$. In addition, a fall in the number of macrophages in sputum and BALF was already evident 1-2 months after smoking cessation, reaching normal levels in BALF at 6 months $[106,115,116]$. BALF neutrophils and lymphocytes normalised at 9 and 15 months, respectively, after smoking cessation [106]. Not only did the number of inflammatory cells in blood and BALF decrease after smoking cessation, but these cells also seemed to be less activated $[112,115]$. In addition, a decrease in pro-inflammatory mediator (soluble intercellular adhesion molecules and soluble CD44) levels has been reported $[110,111]$.

Smoking reduction, like smoking cessation, also reduced airway inflammation. RENNARD et al. [118] investigated the
BALF of 15 heavy smokers who reduced their cigarette consumption from a mean of 50 to 19 cigarettes $\cdot$ day $^{-1}$. After 2 months of smoking reduction, the number of neutrophils and macrophages and elastase levels decreased significantly.

Longitudinal data on blood, BALF and sputum show that smoke-induced changes are reversible after smoking cessation in smokers without chronic respiratory symptoms; however, cross-sectional studies on BALF and sputum suggest that they are only partially reversible. Although longitudinal data on smoking cessation in lung tissue are lacking, the available data indicate that the inflammatory changes in this group of smokers are (at least partially) reversible after smoking cessation.

\section{Chronic bronchitis or chronic obstructive pulmonary disease}

Only a few cross-sectional studies provide any information about the possible effects of smoking cessation in patients with chronic bronchitis or COPD $[85,87,88,93,98,100,101$, 119-125]. A major drawback in most of these studies is that they were not originally designed to compare smokers and exsmokers, and, therefore, the number of subjects was often too small to perform separate analyses.

In the central airways of patients with chronic bronchitis, there was less goblet cell hyperplasia in exsmokers than in smokers. In contrast, there was more squamous metaplasia in exsmokers [88]. In the peripheral airways, goblet cell hyperplasia and squamous metaplasia occurred at similar levels in both groups. More inflammatory cells were present near the secretory glands in the central airways of the exsmokers, which may explain the diminished but still ongoing cough and sputum production after smoking cessation in these patients. More inflammatory cells were present in the wall of the peripheral airways of these exsmokers than in smokers, which contrasted with the lower number of macrophages in the airway lumen in the exsmokers. The presence of glands, smooth muscle mass, fibrosis or cartilage were similar in both groups [88]. It is not yet known whether the composition of inflammatory cells and their mediators in the lungs changes after smoking cessation in patients with chronic bronchitis.

In patients with mild COPD, there tended to be less goblet cell hyperplasia in exsmokers who had quitted smoking for $<2$ yrs than in smokers and exsmokers who had quitted smoking for $>2$ yrs. Goblet cell hyperplasia in the latter two groups was similar. This was a cross-sectional study, and it cannot be ruled out that subjects who had quit for $>2$ yrs had more goblet cell hyperplasia at baseline [119].

The presence of squamous metaplasia, inflammatory cells, fibrosis and muscle hypertrophy in the peripheral airways was similar in exsmokers and smokers with mild COPD. Unlike patients with chronic bronchitis, the number of macrophages in the lumen was similar between smokers and exsmokers with COPD [87, 119]. These data suggest that most pathological changes are not reversible in patients with COPD, except for goblet cell hyperplasia, which seems at least partly reversible.

Although structural changes in COPD patients do not reverse after smoking cessation, FEV1 decline slows. This might be due to a reduction in inflammation in these patients. Indeed, exsmokers showed a lower percentage of B-cells (CD19+) in peripheral blood than smokers, but similar percentages of $\mathrm{CD} 3+, \mathrm{CD} 4+$ and CD8+ T-lymphocytes [93]. Exsmokers and smokers with mild-to-moderate COPD $(n=18)$ showed similar blood levels of soluble tumour necrosis factor (TNF) receptor (sTNFR) 55, sTNFR-75 and IL-8 [101]. However, in a larger group of mild-to-severe COPD patients $(n=55)$, exsmokers exhibited higher levels of sTNFR-55 
and -75 than smokers, which may indicate a decrease in inflammation after smoking cessation [122]. In the latter study, no differences were found in levels of blood leukocytes, acute phase proteins, such as C-reactive protein and lipopolysaccharide-binding protein, and soluble IL-1 receptor type II [122]. Higher levels of sTNFR-55 and -75 were also found in the sputum of exsmokers compared to smokers with mild-to-moderate COPD [101], again indicating a decrease in inflammation upon smoking cessation. In contrast, IL-8 levels were also higher in exsmokers, suggesting increased inflammation. In another group of moderate-to-severe COPD patients, IL-6 and -8 levels in sputum were similar between current and exsmokers [123]. Unfortunately, 51 of the 57 included COPD patients used inhaled corticosteroids; thus

Table 7.-Effect of smoking cessation (SC) on inflammation in blood, sputum and bronchoalveolar lavage fluid (BALF) in smokers without chronic respiratory symptoms

\begin{tabular}{|c|c|c|c|c|c|c|c|}
\hline $\begin{array}{l}\text { First author } \\
\text { [ref.] }\end{array}$ & $\begin{array}{c}\text { Subjects } \\
\mathrm{n}\end{array}$ & $\begin{array}{l}\text { Age } \\
\text { yrs }\end{array}$ & $\begin{array}{l}\text { Cumulative } \\
\text { cigarette } \\
\text { consumption } \\
\text { pack-yrs }\end{array}$ & Specimen & $\begin{array}{l}\text { Validation of } \\
\text { quitters }\end{array}$ & $\begin{array}{l}\text { Follow-up } \\
\text { months }\end{array}$ & Effects of SC \\
\hline
\end{tabular}

\begin{tabular}{|c|c|c|c|c|c|c|c|}
\hline RoBBINS [105] & $10 \mathrm{Q}$ & 38 & $30^{\bullet}$ & eNO & Exhaled CO & 1,8 weeks & $\begin{array}{l}\text { Increase in eNO ( } 5.7 \text { to } 10.3 \mathrm{ppb}) \\
\text { at } 1 / 8 \text { weeks }\end{array}$ \\
\hline \multirow[t]{4}{*}{ MILLER [91] } & $20 \mathrm{Q}$ & $22-71$ & & Blood & & 6 weeks & $\begin{array}{l}\text { No change in } \% \text { lym, CD } 3, \text { CD } 4 \\
\text { or CD } 8 \text { or CD } 4 / C D 8 \text { ratio in } \\
1 \mathrm{Sm} / \mathrm{mSm}\end{array}$ \\
\hline & $5 \mathrm{lSm}$ & & $10-19$ & & & & $\begin{array}{l}\text { Decr in \% CD8, CD4/CD8 ratio } \\
\text { norm in hSm }\end{array}$ \\
\hline & $6 \mathrm{mSm}$ & & $19-49$ & & & & \\
\hline & 9 hSm & & $50-120$ & & & & \\
\hline SKOLD [106] & $18 \mathrm{Q}$ & 41 & 23 & Blood & & $1,3,6,9,15$ & $\begin{array}{l}\text { Decr in leuc and }[\mathrm{Hb}] \text { at } 9 \text { months } \\
\text { Inc in IgG (trend) }\end{array}$ \\
\hline JENSEN [107] & $\begin{array}{l}160 \mathrm{Q} \\
92 \mathrm{Q}\end{array}$ & 43 & 25 & Blood & Exhaled CO & 6,12 & $\begin{array}{l}\text { Decr in leuc, neut, lym; No change } \\
\text { in baso }\end{array}$ \\
\hline JENSEN [108] & $92 \mathrm{Q}$ & 44 & 23 & Blood & Exhaled CO & 6,12 & $\begin{array}{l}\text { Inc in sIgE at } 6 \text { months, esp. in Q } \\
<40 \text { yrs; Decr in sIgE at } 12 \text { months }\end{array}$ \\
\hline MELISKA [109] & $28 \mathrm{Q}(\mathrm{M})$ & $21-35$ & $21^{\bullet}$ & $\begin{array}{l}\text { Blood } \\
\text { (lym) }\end{array}$ & Cotinine & 31 days & $\begin{array}{l}\text { Inc in NK cytotoxic activity; No } \\
\text { change in T-cell activation; Decr } \\
\text { in serum cortisol }\end{array}$ \\
\hline SCOTT [110] & $30 \mathrm{Q}$ & 43 & $25^{\bullet}$ & Plasma & $\begin{array}{l}\text { Exhaled CO, } \\
\text { cotinine }\end{array}$ & 12 & $\begin{array}{l}\text { Decr in sICAMs }\left(307 \text { to } 241 \mathrm{ng} \cdot \mathrm{mL}^{-1}\right) \\
\text { towards normal }\end{array}$ \\
\hline SCOTT [111] & $30 \mathrm{Q}$ & 43 & $25^{\bullet}$ & Plasma & $\begin{array}{l}\text { Exhaled CO, } \\
\text { cotinine }\end{array}$ & 12 & $\begin{array}{l}\text { No change in sCD44; Decr in sCD44v5 } \\
\text { and sCD } 44 \mathrm{v} 6\end{array}$ \\
\hline JENSEN [112] & $50 \mathrm{Q}$ & 39 & 30 & Blood & Exhaled CO & $3,6,12$ & $\begin{array}{l}\text { Decr in } \mathrm{sECP} \text { at } 6 / 12 \text { months } \\
\left(-13.1 \mu \mathrm{g} \cdot \mathrm{L}^{-1}\right) ; \mathrm{Decr} \text { in } \mathrm{sLF} \text { at } 6 / 12 \\
\text { months }\left(-230.7 \mu \mathrm{g} \cdot \mathrm{L}^{-1}\right)\end{array}$ \\
\hline HERSEY [113] & $35 \mathrm{Q}$ & 38 & & Blood & & 3 & $\begin{array}{l}\text { Decr in lym; Trend Decr in neut, plat } \\
\text { Inc in NK activity; Inc in IgG, IgM }\end{array}$ \\
\hline SWAN [114] & $46 \mathrm{Q}$ & 49 & 49 & $\begin{array}{l}\text { Sputum } \\
\text { (spont) }\end{array}$ & $\begin{array}{l}\text { Cotinine in } \\
\text { sputum }\end{array}$ & 12 & $\begin{array}{l}\text { Decr in neut }(-7.9 \%) \text {, MP }(-14 \%) \\
\text { pigm MP }(-4 \%) \text {; No change in } \\
\text { columnar cells, mucus, metaplasia, } \\
\text { dysplasia }\end{array}$ \\
\hline SKOLD [115] & $18 \mathrm{Q}$ & 41 & 23 & BALF & & $1,3,6,9,15$ & $\begin{array}{l}\text { Decr in [cells] at } 1 \text { month; Decr in } \\
\text { oedema, erythema, mucus }{ }^{+} \text {, norm } \\
\text { at } 6 \text { months; Inc in MP Fl at } \\
1 \text { month; Decr in MP Fl at } 6 \text { months }\end{array}$ \\
\hline SKOLD [116] & $18 \mathrm{Q}$ & 41 & 23 & BALF & & $1,3,6$ & $\begin{array}{l}\text { Decr in [cells] at } 1 \text { month; Decr in MP } \\
(91 \text { to } 83 \%) \text { at } 6 \text { months; Inc in MP } \\
\text { activity at } 6 \text { months; Inc in lym } \\
(6.6 \text { to } 14.5 \%) \text { at } 6 \text { months; No } \\
\text { change in } \% \text { neut, eos, baso at } \\
6 \text { months }\end{array}$ \\
\hline SKOLD [106] & $18 \mathrm{Q}$ & 41 & 23 & BALF & & $1,3,6,9,15$ & $\begin{array}{l}\text { Decr in neut, MP, lym, eos (total } \\
\text { cells) at } 9 \text { months; No changes } \\
\text { in L-fibronectin, L-hyaluronan } \\
\text { Inc after SC, norm at } 12 \text { months; } \\
\text { L-albumin Inc at } 6 \text { months } \\
\text { SC, norm at } 12 \text { months }\end{array}$ \\
\hline ANDERSSON [117] & $8 \mathrm{Q}$ & 37 & 20 & BALF & & $1,3,6,9,15$ & $\begin{array}{l}\text { CCSP levels lower in Sm, Inc till } \\
9 \text { months, norm at } 15 \text { months }\end{array}$ \\
\hline
\end{tabular}

Q: quitters; 1Sm: light smokers (Sm); mSm: moderate smokers; hSm: heavy smokers; eNO: exhaled nitric oxide; Inc: increase; Decr: decrease; ppb: parts per billion; lym: lymphocytes; norm: normalised; leuc: leukocytes; Hb: haemoglobin; Ig: immunoglobulin; neut: neutrophils; baso: basophils; sIg: serum Ig; esp.: especially; NK: natural killer [cell]; sICAM: soluble intercellular adhesion molecule; sCD44: soluble CD44; sECP: serum eosinophil cationic protein; sLF: serum lactoferrin; Plat: platelets; spont: spontaneous; MP: macrophages; pigm: pigmented; Fl: fluorescence; eos: eosinophils; CCSP: Clara cell secretory protein. ${ }^{\sharp}$ : same population (subpopulation used in [117]); ": cigarettes $\cdot$ day $^{-1}$ (pack-yrs not given); ${ }^{+}$: macroscopic endobronchial findings. 
the effect of smoking cessation may have been masked by the use of corticosteroids. In spontaneous sputum from mild-tosevere COPD patients who did not use corticosteroids, no differences were found in IL-8, myeloperoxidase and eosinophil cationic protein levels between smokers and exsmokers [126]. In contrast, myeloperoxidase and IL-8 levels in sputum from severe COPD patients were lower in exsmokers. Unfortunately, interpretation is again difficult as 18 of the 42 patients used inhaled corticosteroids. No differences were found between the groups with respect to levels of the neutrophil chemoattractant leukotriene $\mathrm{B}_{4}$ or neutrophil elastase activity, or in the activity of one of the natural inhibitors of neutrophil elastase, secretory leukoprotease inhibitor [127]. Finally, exhaled NO levels in COPD patients are higher in exsmokers than in smokers and nonsmokers $[100,120,121]$, although one study reported no differences [98]. Since exhaled NO is thought to reflect airway inflammation, this suggests a worsening situation. However, NO also has bronchodilatory and anti-inflammatory effects. A major drawback for interpretation is that none of the abovedescribed studies gave specific information on cumulative cigarette consumption or the mean duration of smoking cessation. These data suggest that levels of anti-inflammatory mediators in blood and sputum might increase after smoking cessation, whereas most studies report that the levels of proinflammatory mediators do not change.

Only three studies have investigated bronchial biopsy specimens or lung tissue from smokers and exsmokers with COPD. PEsCI et al. [85] showed that exsmokers tended to have lower numbers of mast cells in the epithelium, lamina propria and BALF than smokers. DE BOER et al. [124] found no differences in expression of IL-8 and MCP-1 and its receptor $\mathrm{CC}$ chemokine receptor 2 in the lung tissue of smokers and exsmokers with moderate-to-severe COPD. Finally, TURATO et al. [125] investigated submucosal inflammation in bronchial biopsy specimens from a group of smoking or exsmoking patients with chronic bronchitis and/or mild-to-moderate COPD, and also from nonsmokers. No differences between smokers (49 pack-yrs) and exsmokers (34 pack-yrs) were found in levels of neutrophils, eosinophils, macrophages and lymphocytes (CD3+, CD4+ and CD8+), and the pro-inflammatory markers TNF- $\alpha$, IL- $1 \beta$ and IL-2 receptor, and expression of the adhesion molecules very late activation antigen-1 (VLA-1), intercellular adhesion molecule-1 (ICAM-1) and E-selectin. However, macrophage numbers and expression of IL-2 receptor, VLA-1, ICAM-1 and E-selectin were higher in both smokers and exsmokers than in nonsmokers. Thus, in COPD patients, inflammation seems to persist in lung tissue after smoking cessation.

The few published studies, presented above, that compare smokers and exsmokers with COPD suggest either a decrease in or persistence of inflammation after smoking cessation. This contradiction may be explained in several ways. First, the design of all of the studies was cross-sectional and studies using bronchial biopsy specimens or lung tissue, especially, contained a small number of subjects. Secondly, the smoking cessation period varied between the studies, or was not described at all. Thirdly, different methods such as biopsy specimens and BALF were used to study inflammation. Fourthly, heterogeneous groups of patients were investigated, both between and within studies. For example, TURATO et al. [125] investigated patients who all showed symptoms of chronic bronchitis, but not all had airway obstruction. Finally and fifthly, not all studies investigated the same biological markers or immunological pathways.

Whether smoking cessation reduces inflammation in COPD patients cannot easily be concluded from the available data. Airway inflammation seems to persist in lung tissue after smoking cessation, whereas studies using sputum, BALF and blood suggest that a reduction occurs, measuring indirect markers of airway inflammation. In addition, goblet cell hyperplasia seems to be at least partially reversible, whereas most of the pathological changes are not.

\section{Discussion}

Ideally, the results of longitudinal prospective studies would be reviewed to assess the effects of smoking cessation on the lungs. This was to some extent feasible with respect to the effects of smoking cessation on respiratory symptoms and FEV1 in smokers without chronic respiratory symptoms. However, longitudinal data describing the effects of smoking cessation on airway inflammation in patients with established COPD are lacking. Only 14 cross-sectional studies have been published, describing airway inflammation and comparing smokers and exsmokers. Obviously, there is an astonishing discrepancy between the global consensus that smoking cessation is one of the most important health issues and the very scarce information regarding its effects on the lungs. In the following section, the findings described above are summarised, with special attention to the contrasting results between smokers without chronic respiratory symptoms and smokers with chronic bronchitis and COPD.

\section{Smokers without chronic respiratory symptoms}

Smoking cessation decreases episodic respiratory symptoms and normalises the excessive decline in FEV1. It does not improve AHR to direct stimuli, but prevents future deterioration. Smoking cessation reduces the number of goblet cells in the peripheral airways, which may explain why respiratory symptoms such as cough and sputum production decrease in this group. Smoking cessation does not change smooth muscle mass and fibrosis in the peripheral airways; however, it improves peripheral airway collapse in the single-breath nitrogen-washout test. The present authors are not aware of any histological studies that show whether smoking cessation reduces local inflammatory cell infiltration in the airway wall and parenchyma. Nevertheless, the levels of inflammatory cells and inflammatory mediators in blood, sputum and BALF decrease towards normal values within $1 \mathrm{yr}$ of smoking cessation. Thus most studies in smokers without chronic respiratory symptoms suggest that the smoke-induced subtle changes in the lung (especially in the peripheral airways) are at least partially reversible.

\section{Chronic bronchitis}

The effect of smoking cessation on sputum production, dyspnoea, FEV1, AHR and inflammation has not formally been investigated in chronic bronchitis, reflecting the neglect shown towards this disease since the 1970s. Smoking cessation evidently decreases chronic cough, most probably due to a decrease in goblet cell number in the central airways. Moreover, it is associated with normalisation of the accelerated decline in lung function, similar to that seen in smokers without chronic respiratory symptoms. In contrast, smoking cessation does not reduce the number of goblet cells or submucosal glands, smooth muscle mass or fibrosis in the peripheral airways. Taken together, the few available studies in these patients suggest that smoking cessation reduces bronchitis of the large airways, resulting in a reduction of cough and accelerated decline in FEV1. 


\section{Chronic obstructive pulmonary disease}

The most important clinical features of COPD patients are respiratory symptoms and an accelerated decline in FEV1. Smoking cessation in COPD patients improves respiratory symptoms and normalises the excessive FEV1 decline in all stages of the disease. The improvement in respiratory symptoms may be caused by a decrease in goblet cell number, just as in healthy smokers and smokers with chronic bronchitis. Indirect bronchial hyperresponsiveness seems to improve after smoking cessation. After smoking cessation, an increase in anti-inflammatory receptor levels in blood and sputum occurs in mild-to-severe COPD patients. In addition, levels of neutrophil chemoattractants in sputum are reduced in severe COPD. Taken together, this suggests an improvement of inflammation. However, no effects of smoking cessation on blood leukocyte numbers or acute phase protein levels, or on inflammatory cell numbers and mediators in lung tissue, occur.

In summary, although some indirect markers of airway inflammation suggest a reduction in inflammation after smoking cessation in COPD patients, histopathological studies show persistent airway inflammation. Since smoking cessation improves respiratory symptoms and slows the rapid FEV1 decline in COPD patients, it is obvious that the primary therapeutic intervention for these patients is to quit smoking. However, the exact nature of the changes in airway inflammation and the relationship with symptoms, lung function and AHR after smoking cessation remain to be established.

\section{Conclusion}

Smoking cessation improves respiratory symptoms and bronchial hyperresponsiveness, and prevents accelerated decline in lung function, in all smokers, with or without chronic obstructive pulmonary disease. In chronic obstructive pulmonary disease, the underlying fibrosis and loss of alveolar attachments is probably irreversible, explaining why the forced expiratory volume in one second does not normalise after smoking cessation in these patients. It is now well established that smoking cessation improves the accelerated decline in forced expiratory volume in one second, which strongly indicates that smoking cessation positively influences important inflammatory and/or remodelling processes in the lungs. Thus it is attractive to speculate that remodelling may indeed be influenced to some extent by smoking cessation; however, acute inflammatory processes are ongoing, which may simply reflect a repair (remodelling) process but not ongoing damage to the airways and lung tissue. Therefore, the challenge for future research is to investigate the relevant biological markers that represent these changes. Further information regarding the persistence of inflammation after smoking cessation is important and may offer a target for future pharmacological interventions.

\section{References}

1. Siafakas NM, Vermeire $\mathrm{P}$, Pride NB, et al. Optimal assessment and management of chronic obstructive pulmonary disease (COPD). Eur Respir J 1995; 8: 1398-1420.

2. Kanner RE, Connett JE, Williams DE, Buist AS. Effects of randomized assignment to a smoking cessation intervention and changes in smoking habits on respiratory symptoms in smokers with early chronic obstructive pulmonary disease: the Lung Health Study. Am J Med 1999; 106: 410-416.
3. Anthonisen NR. Epidemiology and the Lung Health Study. Eur Respir Rev 1997; 7: 45, 202-205.

4. Rijcken B, Britton J. Epidemiology of chronic obstructive pulmonary disease. Eur Respir Mon 1998; 3: 7, 41-73.

5. Niewoehner DE, Kleinerman J, Rice DB. Pathologic changes in the peripheral airways of young cigarette smokers. N Engl J Med 1974; 291: 755-758.

6. Samet JM, Lange P. Longitudinal studies of active and passive smoking. Am J Respir Crit Care Med 1996; 154: S257-S265.

7. Lange $\mathrm{P}$, Groth $\mathrm{S}$, Nyboe $\mathrm{J}$, et al. Decline of the lung function related to the type of tobacco smoked and inhalation. Thorax 1990; 45: 22-26.

8. Lange P, Groth S, Nyboe GJ, et al. Effects of smoking and changes in smoking habits on the decline of FEV1. Eur Respir J 1989; 2: 811-816.

9. Sobonya RE, Kleinerman J. Morphometric studies of bronchi in young smokers. Am Rev Respir Dis 1972; 105: 768-775.

10. Pauwels RA, Buist AS, Calverley PM, Jenkins CR, Hurd SS. Global strategy for the diagnosis, management, and prevention of chronic obstructive pulmonary disease. NHLBI/ WHO Global Initiative for Chronic Obstructive Lung Disease (GOLD) Workshop summary. Am J Respir Crit Care Med 2001; 163: 1256-1276.

11. Bjornsson E, Plaschke P, Norrman E, et al. Symptoms related to asthma and chronic bronchitis in three areas of Sweden. Eur Respir J 1994; 7: 2146-2153.

12. Brown CA, Crombie IK, Smith WC, Tunstall-Pedoe H. The impact of quitting smoking on symptoms of chronic bronchitis: results of the Scottish Heart Health Study. Thorax 1991; 46: 112-116.

13. Enright PL, Kronmal RA, Higgins MW, Schenker MB, Haponik EF. Prevalence and correlates of respiratory symptoms and disease in the elderly. Cardiovascular Health Study. Chest 1994; 106: 827-834.

14. Lundback B, Nystrom L, Rosenhall L, Stjernberg N. Obstructive lung disease in northern Sweden: respiratory symptoms assessed in a postal survey. Eur Respir J 1991; 4: 257-266.

15. Rijcken B, Schouten JP, Weiss ST, Speizer FE, van der Lende R. The relationship of nonspecific bronchial responsiveness to respiratory symptoms in a random population sample. Am Rev Respir Dis 1987; 136: 62-68.

16. Sherman CB, Xu X, Speizer FE, Ferris BG Jr, Weiss ST, Dockery DW. Longitudinal lung function decline in subjects with respiratory symptoms. Am Rev Respir Dis 1992; 146: 855-859.

17. Sherrill DL, Lebowitz MD, Knudson RJ, Burrows B. Longitudinal methods for describing the relationship between pulmonary function, respiratory symptoms and smoking in elderly subjects: the Tucson Study. Eur Respir J 1993; 6: 342-348.

18. Sparrow D, O'Connor G, Colton T, Barry CL, Weiss ST. The relationship of nonspecific bronchial responsiveness to the occurrence of respiratory symptoms and decreased levels of pulmonary function. The Normative Aging Study. Am Rev Respir Dis 1987; 135: 1255-1260.

19. Viegi G, Paoletti P, Prediletto R, et al. Prevalence of respiratory symptoms in an unpolluted area of northern Italy. Eur Respir J 1988; 1: 311-318.

20. Higenbottam T, Clark TJ, Shipley MJ, Rose G. Lung function and symptoms of cigarette smokers related to tar yield and number of cigarettes smoked. Lancet 1980; 1: 409411.

21. Comstock GW, Brownlow WJ, Stone RW, Sartwell PE. Cigarette smoking and changes in respiratory findings. Arch Environ Health 1970; 21: 50-57.

22. Barbee RA, Halonen M, Kaltenborn WT, Burrows B. A longitudinal study of respiratory symptoms in a community population sample. Correlations with smoking, allergen skintest reactivity, and serum IgE. Chest 1991; 99: 20-26. 
23. Buczko GB, Day A, Vanderdoelen JL, Boucher R, Zamel N. Effects of cigarette smoking and short-term smoking cessation on airway responsiveness to inhaled methacholine. Am Rev Respir Dis 1984; 129: 12-14.

24. Buist AS, Sexton GJ, Nagy JM, Ross BB. The effect of smoking cessation and modification on lung function. Am Rev Respir Dis 1976; 114: 115-122.

25. Tashkin DP, Clark VA, Coulson AH, et al. The UCLA population studies of chronic obstructive respiratory disease. VIII. Effects of smoking cessation on lung function: a prospective study of a free-living population. Am Rev Respir Dis 1984; 130: 707-715.

26. Wilhelmsen L. Effects on bronchopulmonary symptoms, ventilation, and lung mechanics of abstinence from tobacco smoking. Scand J Respir Dis 1967; 48: 407-414.

27. Israel RH, Ossip-Klein DJ, Poe RH, et al. Bronchial provocation tests before and after cessation of smoking. Respiration 1988; 54: 247-254.

28. Krzyzanowski M, Robbins DR, Lebowitz MD. Smoking cessation and changes in respiratory symptoms in two populations followed for 13 years. Int J Epidemiol 1993; 22: 666-673.

29. Lange $\mathrm{P}$, Groth $\mathrm{S}$, Nyboe $\mathrm{J}$, et al. Phlegm production in plain cigarette smokers who changed to filter cigarettes or quit smoking. J Intern Med 1990; 228: 115-120.

30. Peterson DI, Lonergan LH, Hardinge MG. Smoking and pulmonary function. Arch Environ Health 1968; 16: 215-218.

31. von Hertzen L, Reunanen A, Impivaara O, Malkia E, Aromaa A. Airway obstruction in relation to symptoms in chronic respiratory disease - a nationally representative population study. Respir Med 2000; 94: 356-363.

32. Friedman GD, Siegelaub AB. Changes after quitting cigarette smoking. Circulation 1980; 61: 716-723.

33. Buist AS, Connett JE, Miller RD, Kanner RE, Owens GR, Voelker HT. Chronic Obstructive Pulmonary Disease Early Intervention Trial (Lung Health Study). Baseline characteristics of randomized participants. Chest 1993; 103: 18631872.

34. Pride NB. Smoking cessation: effects on symptoms, spirometry and future trends in COPD. Thorax 2001; 56: Suppl. 2, II7-II10.

35. Lebowitz MD, Holberg CJ, Knudson RJ, Burrows B. Longitudinal study of pulmonary function development in childhood, adolescence, and early adulthood. Development of pulmonary function. Am Rev Respir Dis 1987; 136: 69-75.

36. Enjeti S, Hazelwood B, Permutt S, Menkes H, Terry P. Pulmonary function in young smokers: male-female differences. Am Rev Respir Dis 1978; 118: 667-676.

37. Nemery B, Moavero NE, Brasseur L, Stanescu DC. Changes in lung function after smoking cessation: an assessment from a cross-sectional survey. Am Rev Respir Dis 1982; 125: 122124.

38. Ekberg-Jansson A, Bake B, Andersson B, Skoogh BE, Lofdahl CG. Respiratory symptoms relate to physiological changes and inflammatory markers reflecting central but not peripheral airways. A study in 60-year-old 'healthy' smokers and never-smokers. Respir Med 2001; 95: 40-47.

39. Xu X, Dockery DW, Ware JH, Speizer FE, Ferris BG Jr. Effects of cigarette smoking on rate of loss of pulmonary function in adults: a longitudinal assessment. Am Rev Respir Dis 1992; 146: 1345-1348.

40. Dockery DW, Speizer FE, Ferris BG Jr, Ware JH, Louis TA, Spiro A III. Cumulative and reversible effects of lifetime smoking on simple tests of lung function in adults. Am Rev Respir Dis 1988; 137: 286-292.

41. Chen Y, Horne SL, Dosman JA. Increased susceptibility to lung dysfunction in female smokers. Am Rev Respir Dis 1991; 143: 1224-1230.

42. Sorlie P, Lakatos E, Kannel WB, Celli B. Influence of cigarette smoking on lung function at baseline and at followup in 14 years: the Framingham Study. J Chronic Dis 1987; 40: $849-856$.
43. Burr ML, Phillips KM, Hurst DN. Lung function in the elderly. Thorax 1985; 40: 54-59.

44. Sherrill DL, Enright P, Cline M, Burrows B, Lebowitz MD. Rates of decline in lung function among subjects who restart cigarette smoking. Chest 1996; 109: 1001-1005.

45. Burchfiel CM, Marcus EB, Curb JD, et al. Effects of smoking and smoking cessation on longitudinal decline in pulmonary function. Am J Respir Crit Care Med 1995; 151: 1778-1785.

46. Bosse R, Sparrow D, Rose CL, Weiss ST. Longitudinal effect of age and smoking cessation on pulmonary function. Am Rev Respir Dis 1981; 123: 378-381.

47. Camilli AE, Burrows B, Knudson RJ, Lyle SK, Lebowitz MD. Longitudinal changes in forced expiratory volume in one second in adults. Effects of smoking and smoking cessation. Am Rev Respir Dis 1987; 135: 794-799.

48. Tager IB, Segal MR, Speizer FE, Weiss ST. The natural history of forced expiratory volumes. Effect of cigarette smoking and respiratory symptoms. Am Rev Respir Dis 1988; 138: 837-849.

49. Xu X, Weiss ST, Rijcken B, Schouten JP. Smoking, changes in smoking habits, and rate of decline in FEV1: new insight into gender differences. Eur Respir J 1994; 7 : 1056-1061.

50. Beaty TH, Menkes HA, Cohen BH, Newill CA. Risk factors associated with longitudinal change in pulmonary function. Am Rev Respir Dis 1984; 129: 660-667.

51. Pelkonen M, Notkola IL, Tukiainen H, Tervahauta M, Tuomilehto J, Nissinen A. Smoking cessation, decline in pulmonary function and total mortality: a 30 year follow up study among the Finnish cohorts of the Seven Countries Study. Thorax 2001; 56: 703-707.

52. Krzyzanowski M, Jedrychowski W, Wysocki M. Factors associated with the change in ventilatory function and the development of chronic obstructive pulmonary disease in a 13-year follow-up of the Cracow Study. Risk of chronic obstructive pulmonary disease. Am Rev Respir Dis 1986; 134: 1011-1019.

53. Taylor RG, Joyce H, Gross E, Holland F, Pride NB. Bronchial reactivity to inhaled histamine and annual rate of decline in FEV1 in male smokers and ex-smokers. Thorax 1985; 40: 9-16.

54. Kabiraj MU, Simonsson BG, Groth S, Bjorklund A, Bulow $\mathrm{K}$, Lindell SE. Bronchial reactivity, smoking, and $\alpha_{1^{-}}$ antitrypsin. A population-based study of middle-aged men. Am Rev Respir Dis 1982; 126: 864-869.

55. Townsend MC, DuChene AG, Morgan J, Browner WS. Pulmonary function in relation to cigarette smoking and smoking cessation. MRFIT Research Group. Prev Med 1991; 20: 621-637.

56. Krzyzanowski M, Camilli AE, Lebowitz MD. Relationships between pulmonary function and changes in chronic respiratory symptoms. Comparison of Tucson and Cracow longitudinal studies. Chest 1990; 98: 62-70.

57. Sherrill DL, Lebowitz MD, Knudson RJ, Burrows B. Smoking and symptom effects on the curves of lung function growth and decline. Am Rev Respir Dis 1991; 144: 17-22.

58. Rijcken B, Schouten JP, Weiss ST, Speizer FE, van der Lende $\mathrm{R}$. The association of airways responsiveness to respiratory symptom prevalence and to pulmonary function in a random population sample. Bull Eur Physiopathol Respir 1987; 23: 391-394.

59. Buist AS, Nagy JM, Sexton GJ. The effect of smoking cessation on pulmonary function: a 30-month follow-up of two smoking cessation clinics. Am Rev Respir Dis 1979; 120: 953-957.

60. Bode FR, Dosman J, Martin RR, Macklem PT. Reversibility of pulmonary function abnormalities in smokers. A prospective study of early diagnostic tests of small airways disease. Am J Med 1975; 59: 43-52.

61. Simonsson BG, Rolf C. Bronchial reactivity to methacholine in ten non-obstructive heavy smokers before and up to one 
year after cessation of smoking. Eur J Respir Dis 1982; 63: $526-534$

62. McCarthy DS, Craig DB, Cherniack RM. Effect of modification of the smoking habit on lung function. $\mathrm{Am}$ Rev Respir Dis 1976; 114: 103-113.

63. Fletcher C, Peto R. The natural history of chronic airflow obstruction. BMJ 1977; 1: 1645-1648.

64. Anthonisen NR, Connett JE, Kiley JP, et al. Effects of smoking intervention and the use of an inhaled anticholinergic bronchodilator on the rate of decline of FEV1. The Lung Health Study. JAMA 1994; 272: 1497-1505.

65. Scanlon PD, Connett JE, Waller LA, Altose MD, Bailey WC, Buist AS. Smoking cessation and lung function in mild-tomoderate chronic obstructive pulmonary disease. The Lung Health Study. Am J Respir Crit Care Med 2000; 161: 381390.

66. Murray RP, Anthonisen NR, Connett JE, et al. Effects of multiple attempts to quit smoking and relapses to smoking on pulmonary function. Lung Health Study Research Group. J Clin Epidemiol 1998; 51: 1317-1326.

67. Postma DS, de Vries K, Koeter GH, Sluiter HJ. Independent influence of reversibility of air-flow obstruction and nonspecific hyperreactivity on the long-term course of lung function in chronic air-flow obstruction. Am Rev Respir Dis 1986; 134: 276-280.

68. Postma DS, Sluiter HJ. Prognosis of chronic obstructive pulmonary disease: the Dutch experience. Am Rev Respir Dis 1989; 140: S100-S105.

69. Barter CE, Campbell AH. Relationship of constitutional factors and cigarette smoking to decrease in 1-second forced expiratory volume. Am Rev Respir Dis 1976; 113: 305-314.

70. Hughes JA, Hutchison DC, Bellamy D, Dowd DE, Ryan KC, Hugh-Jones P. The influence of cigarette smoking and its withdrawal on the annual change of lung function in pulmonary emphysema. $Q J$ Med 1982; 51: 115-124.

71. Anthonisen NR, Connett JE, Murray RP. Smoking and lung function of Lung Health Study participants after 11 years. Am J Respir Crit Care Med 2002; 166: 675-679.

72. Leader WG, Wolf KM, Cooper TM, Chandler MH. Symptomatology, pulmonary function and response, and $\mathrm{T}$ lymphocyte beta 2-receptors during smoking cessation in patients with chronic obstructive pulmonary disease. Pharmacotherapy 1994; 14: 162-172.

73. Lim TK, Taylor RG, Watson A, Joyce H, Pride NB. Changes in bronchial responsiveness to inhaled histamine over four years in middle aged male smokers and exsmokers. Thorax 1988; 43: 599-604.

74. Cerveri I, Bruschi C, Zoia MC, et al. Smoking habit and bronchial reactivity in normal subjects. A population-based study. Am Rev Respir Dis 1989; 140: 191-196.

75. Paoletti P, Carrozzi L, Viegi G, et al. Distribution of bronchial responsiveness in a general population: effect of sex, age, smoking, and level of pulmonary function. $\mathrm{Am}$ J Respir Crit Care Med 1995; 151: 1770-1777.

76. Sunyer J, Anto JM, Kogevinas M, Soriano JB, Tobias A, Munoz A. Smoking and bronchial responsiveness in nonatopic and atopic young adults. Spanish Group of the European Study of Asthma. Thorax 1997; 52: 235-238.

77. Sparrow D, O'Connor GT, Rosner B, Segal MR, Weiss ST. The influence of age and level of pulmonary function on nonspecific airway responsiveness. The Normative Aging Study. Am Rev Respir Dis 1991; 143: 978-982.

78. Burney PG, Britton JR, Chinn S, et al. Descriptive epidemiology of bronchial reactivity in an adult population: results from a community study. Thorax 1987; 42: 38-44.

79. Xu X, Rijcken B, Schouten JP, Weiss ST. Airways responsiveness and development and remission of chronic respiratory symptoms in adults. Lancet 1997; 350: 14311434.

80. Tashkin DP, Altose MD, Bleecker ER, et al. The lung health study: airway responsiveness to inhaled methacholine in smokers with mild to moderate airflow limitation. The Lung
Health Study Research Group. Am Rev Respir Dis 1992; 145: 301-310.

81. Oosterhoff Y, de Jong JW, Jansen MA, Koeter GH, Postma DS. Airway responsiveness to adenosine 5'monophosphate in chronic obstructive pulmonary disease is determined by smoking. Am Rev Respir Dis 1993; 147: 553-558.

82. Postma DS, Renkema TE, Noordhoek JA, Faber H, Sluiter HJ, Kauffman H. Association between nonspecific bronchial hyperreactivity and superoxide anion production by polymorphonuclear leukocytes in chronic air-flow obstruction. Am Rev Respir Dis 1988; 137: 57-61.

83. Bahous J, Cartier A, Ouimet G, Pineau L, Malo JL. Nonallergic bronchial hyperexcitability in chronic bronchitis. Am Rev Respir Dis 1984; 129: 216-220.

84. Woolcock AJ, Anderson SD, Peat JK, et al. Characteristics of bronchial hyperresponsiveness in chronic obstructive pulmonary disease and in asthma. Am Rev Respir Dis 1991; 143: 1438-1443.

85. Pesci A, Rossi GA, Bertorelli G, Aufiero A, Zanon P, Olivieri D. Mast cells in the airway lumen and bronchial mucosa of patients with chronic bronchitis. Am J Respir Crit Care Med 1994; 149: 1311-1316.

86. Wise RA, Kanner RE, Lindgren $\mathrm{P}$, et al. The effect of smoking intervention and an inhaled bronchodilator on airways reactivity in COPD: the Lung Health Study. Chest 2003; 124: 449-458.

87. Wright JL, Hobson JE, Wiggs B, Pare PD, Hogg JC. Airway inflammation and peribronchiolar attachments in the lungs of nonsmokers, current and ex-smokers. Lung 1988; 166 : 277-286.

88. Mullen JB, Wright JL, Wiggs BR, Pare PD, Hogg JC. Structure of central airways in current smokers and ex-smokers with and without mucus hypersecretion: relationship to lung function. Thorax 1987; 42: 843-848.

89. Sunyer J, Munoz A, Peng Y, et al. Longitudinal relation between smoking and white blood cells. Am J Epidemiol 1996; 144: 734-741.

90. Tollerud DJ, Clark JW, Brown LM, et al. The effects of cigarette smoking on $\mathrm{T}$ cell subsets. A population-based survey of healthy Caucasians. Am Rev Respir Dis 1989; 139: 1446-1451.

91. Miller LG, Goldstein G, Murphy M, Ginns LC. Reversible alterations in immunoregulatory T cells in smoking. Analysis by monoclonal antibodies and flow cytometry. Chest 1982; 82: 526-529.

92. Holt PG. Immune and inflammatory function in cigarette smokers. Thorax 1987; 42: 241-249.

93. de Jong JW, Belt-Gritter B, Koeter GH, Postma DS. Peripheral blood lymphocyte cell subsets in subjects with chronic obstructive pulmonary disease: association with smoking, IgE and lung function. Respir Med 1997; 91: 67-76.

94. Tollerud DJ, Clark JW, Brown LM, et al. Association of cigarette smoking with decreased numbers of circulating natural killer cells. Am Rev Respir Dis 1989; 139: 194-198.

95. Persson MG, Zetterstrom O, Agrenius V, Ihre E, Gustafsson LE. Single-breath nitric oxide measurements in asthmatic patients and smokers. Lancet 1994; 343: 146-147.

96. Schilling J, Holzer $\mathrm{P}$, Guggenbach $\mathrm{M}$, Gyurech D, Marathia K, Geroulanos S. Reduced endogenous nitric oxide in the exhaled air of smokers and hypertensives. Eur Respir J 1994; 7: 467-471.

97. Delen FM, Sippel JM, Osborne ML, Law S, Thukkani N, Holden WE. Increased exhaled nitric oxide in chronic bronchitis: comparison with asthma and COPD. Chest 2000; 117: 695-701.

98. Rutgers SR, van der Mark TW, Coers W, et al. Markers of nitric oxide metabolism in sputum and exhaled air are not increased in chronic obstructive pulmonary disease. Thorax 1999; 54: 576-580.

99. Balint B, Donnelly LE, Hanazawa T, Kharitonov SA, Barnes PJ. Increased nitric oxide metabolites in exhaled 
breath condensate after exposure to tobacco smoke. Thorax 2001; 56: 456-461.

100. Montuschi P, Kharitonov SA, Barnes PJ. Exhaled carbon monoxide and nitric oxide in COPD. Chest 2001; 120: 496501.

101. Vernooy JH, Kucukaycan M, Jacobs JA, et al. Local and systemic inflammation in patients with chronic obstructive pulmonary disease: soluble tumor necrosis factor receptors are increased in sputum. Am J Respir Crit Care Med 2002; 166: $1218-1224$.

102. Keatings VM, Collins PD, Scott DM, Barnes PJ. Differences in interleukin- 8 and tumor necrosis factor- $\alpha$ in induced sputum from patients with chronic obstructive pulmonary disease or asthma. Am J Respir Crit Care Med 1996; 153: $530-534$.

103. Chalmers GW, MacLeod KJ, Thomson L, Little SA, McSharry C, Thomson NC. Smoking and airway inflammation in patients with mild asthma. Chest 2001; 120: 19171922.

104. Capelli A, Di Stefano A, Gnemmi I, et al. Increased MCP-1 and MIP-1 $\beta$ in bronchoalveolar lavage fluid of chronic bronchitics. Eur Respir J 1999; 14: 160-165.

105. Robbins RA, Millatmal T, Lassi K, Rennard S, Daughton D. Smoking cessation is associated with an increase in exhaled nitric oxide. Chest 1997; 112: 313-318.

106. Skold CM, Blaschke E, Eklund A. Transient increases in albumin and hyaluronan in bronchoalveolar lavage fluid after quitting smoking: possible signs of reparative mechanisms. Respir Med 1996; 90: 523-529.

107. Jensen EJ, Pedersen B, Frederiksen R, Dahl R. Prospective study on the effect of smoking and nicotine substitution on leucocyte blood counts and relation between blood leucocytes and lung function. Thorax 1998; 53: 784-789.

108. Jensen EJ, Pedersen B, Schmidt E, Dahl R. Serum IgE in nonatopic smokers, nonsmokers, and recent exsmokers: relation to lung function, airway symptoms, and atopic predisposition. J Allergy Clin Immunol 1992; 90: 224-229.

109. Meliska CJ, Stunkard ME, Gilbert DG, Jensen RA, Martinko JM. Immune function in cigarette smokers who quit smoking for 31 days. J Allergy Clin Immunol 1995; 95: 901-910.

110. Scott DA, Stapleton JA, Wilson RF, et al. Dramatic decline in circulating intercellular adhesion molecule-1 concentration on quitting tobacco smoking. Blood Cells Mol Dis 2000; 26: 255-258.

111. Scott DA, Stapleton JA, Palmer RM, et al. Plasma concentrations of reputed tumor-associated soluble CD44 isoforms (v5 and v6) in smokers are dose related and decline on smoking cessation. Cancer Epidemiol Biomarkers Prev 2000; 9: 1211-1214.

112. Jensen EJ, Pedersen B, Schmidt E, Venge P, Dahl R. Serum eosinophilic cationic protein and lactoferrin related to smoking history and lung function. Eur Respir J 1994; 7 : 927-933.

113. Hersey P, Prendergast D, Edwards A. Effects of cigarette smoking on the immune system. Follow-up studies in normal subjects after cessation of smoking. Med J Aust 1983; 2: 425429.

114. Swan GE, Hodgkin JE, Roby T, Mittman C, Jacobo N, Peters J. Reversibility of airways injury over a 12-month period following smoking cessation. Chest 1992; 101: 607612.

115. Skold CM, Hed J, Eklund A. Smoking cessation rapidly reduces cell recovery in bronchoalveolar lavage fluid, while alveolar macrophage fluorescence remains high. Chest 1992; 101: 989-995.

116. Skold CM, Forslid J, Eklund A, Hed J. Metabolic activity in human alveolar macrophages increases after cessation of smoking. Inflammation 1993; 17: 345-352.

117. Andersson O, Cassel TN, Skold CM, Eklund A, Lund J, Nord M. Clara cell secretory protein. Levels in BAL fluid after smoking cessation. Chest 2000; 118: 180-182.

118. Rennard SI, Daughton D, Fujita J, et al. Short-term smoking reduction is associated with reduction in measures of lower respiratory tract inflammation in heavy smokers. Eur Respir J 1990; 3: 752-759.

119. Wright JL, Lawson LM, Pare PD, Wiggs BJ, Kennedy S, Hogg JC. Morphology of peripheral airways in current smokers and ex-smokers. Am Rev Respir Dis 1983; 127: 474 477.

120. Corradi M, Majori M, Cacciani GC, Consigli GF, $\mathrm{de}^{\prime}$ Munari E, Pesci A. Increased exhaled nitric oxide in patients with stable chronic obstructive pulmonary disease. Thorax 1999; 54: 572-575.

121. Maziak W, Loukides S, Culpitt S, Sullivan P, Kharitonov SA, Barnes PJ. Exhaled nitric oxide in chronic obstructive pulmonary disease. Am J Respir Crit Care Med 1998; 157: 998-1002.

122. Dentener MA, Creutzberg EC, Schols AM, et al. Systemic anti-inflammatory mediators in COPD: increase in soluble interleukin 1 receptor II during treatment of exacerbations. Thorax 2001; 56: 721-726.

123. Bhowmik A, Seemungal TA, Sapsford RJ, Wedzicha JA. Relation of sputum inflammatory markers to symptoms and lung function changes in COPD exacerbations. Thorax 2000; 55: $114-120$

124. de Boer WI, Sont JK, van Schadewijk A, Stolk J, van Krieken JH, Hiemstra PS. Monocyte chemoattractant protein 1 , interleukin 8 , and chronic airways inflammation in COPD. J Pathol 2000; 190: 619-626.

125. Turato G, Di Stefano A, Maestrelli P, et al. Effect of smoking cessation on airway inflammation in chronic bronchitis. Am J Respir Crit Care Med 1995; 152: 1262-1267.

126. Yamamoto $\mathrm{C}$, Yoneda $\mathrm{T}$, Yoshikawa $\mathrm{M}$, et al. Airway inflammation in COPD assessed by sputum levels of interleukin-8. Chest 1997; 112: 505-510.

127. Hill AT, Bayley DL, Campbell EJ, Hill SL, Stockley RA. Airways inflammation in chronic bronchitis: the effects of smoking and $\alpha_{1}$-antitrypsin deficiency. Eur Respir $J$ 2000; 15 : 886-890. 